\title{
Review of Works Combining GNSS and InSAR in Europe
}

\author{
Matteo Del Soldato *(D), Pierluigi Confuorto (D), Silvia Bianchini (D), Paolo Sbarra and Nicola Casagli (D) \\ Earth Science Department of the University of Firenze, Via La Pira 4, 50121 Firenze, Italy; \\ pierluigi.confuorto@unifi.it (P.C.); silvia.bianchini@unifi.it (S.B.); paolo.sbarra@stud.unifi.it (P.S.); \\ nicola.casagli@unifi.it (N.C.) \\ * Correspondence: matteo.delsoldato@unifi.it; Tel.: +39-0552757551
}

Citation: Del Soldato, M.; Confuorto, P.; Bianchini, S.; Sbarra, P.; Casagli, N. Review of Works Combining GNSS and InSAR in Europe. Remote Sens. 2021, 13, 1684. https://doi.org/ $10.3390 / \mathrm{rs} 13091684$

Academic Editor: Mimmo Palano

Received: 31 March 2021

Accepted: 24 April 2021

Published: 27 April 2021

Publisher's Note: MDPI stays neutral with regard to jurisdictional claims in published maps and institutional affiliations.

Copyright: (c) 2021 by the authors. Licensee MDPI, Basel, Switzerland. This article is an open access article distributed under the terms and conditions of the Creative Commons Attribution (CC BY) license (https:/ / creativecommons.org/licenses/by/ $4.0 /)$.

\begin{abstract}
The Global Navigation Satellite System (GNSS) and Synthetic Aperture Radar Interferometry (InSAR) can be combined to achieve different goals, owing to their main principles. Both enable the collection of information about ground deformation due to the differences of two consequent acquisitions. Their variable applications, even if strictly related to ground deformation and water vapor determination, have encouraged the scientific community to combine GNSS and InSAR data and their derivable products. In this work, more than 190 scientific contributions were collected spanning the whole European continent. The spatial and temporal distribution of such studies, as well as the distinction in different fields of application, were analyzed. Research in Italy, as the most represented nation, with 47 scientific contributions, has been dedicated to the spatial and temporal distribution of its studied phenomena. The state-of-the-art of the various applications of these two combined techniques can improve the knowledge of the scientific community and help in the further development of new approaches or additional applications in different fields. The demonstrated usefulness and versability of the combination of GNSS and InSAR remote sensing techniques for different purposes, as well as the availability of free data, EUREF and GMS (Ground Motion Service), and the possibility of overcoming some limitations of these techniques through their combination suggest an increasingly widespread approach.
\end{abstract}

Keywords: GNSS; GPS; InSAR; Europe; Italy; PS

\section{Introduction}

The Global Navigation Satellite System (GNSS) and Synthetic Aperture Radar Interferometry (InSAR) can be used for various applications owing to their principal functions. GPS enables the collection of three-dimensional (3D) deformation information, considering the coordinates of surveyed points. Since the 1970s, InSAR [1] has permitted the investigation of the phase difference (interferogram) between two images acquired over the same area at different times.

The GNSS term refers to any satellite constellation that provides information globally about the positioning, timing, and navigation data of elements to a GNSS receiver that then commutes this information to a precise location. The GNSS family includes several regional satellite systems, e.g., GPS (Global Positioning System), Galileo, and GLONASS (GLObal'naya NAvigatsionnaya Sputnikovaya System). GNSS performances are (i) accurate in the determination of real position, velocity and time of travel between the transmitter and receiver; (ii) intact, allowing the insertion of an alarm in case of anomaly positioning; (iii) able to work continuously without interruptions; and (iv) able to fulfil all the criteria of accuracy, integrity, and continuity. This system provides three-dimensional along the East-West, North-South, and up-down direction for ongoing deformation through the precise determination of the receiver position with millimetric accuracy in order to assess the main components. GNSS is very useful for investigating regionally low spatial frequencies, e.g., tectonic or geodynamic deformation fields, but local patterns or movements cannot be appreciated due to the large distance between adjacent GNSS stations. The 
main limitation of the measurement approach of GNSS is a lack of data in some areas due to the absence of GNSS stations since this technique is station-dependent [2]; however, the European continent is sufficiently covered by more than 300 distributed multi-GNSS reference stations [3].

The InSAR approach is a consolidated remote sensing technique employed for the detection and monitoring of ground deformation that has become widely used over the last decade. The first application dates back to the late 1980s [4] and was based on the DInSAR (Differential InSAR) approach that enabled the collection of cumulative deformation derived from the phase difference of two subsequent SAR acquisitions captured during two consecutive satellite passages over the same area. The transition from a single interferogram (DInSAR) to a multi-interferogram approach permitted a multi-temporal analysis (MTInSAR, Multi Temporal InSAR) [5], which sensibly and rapidly improved the investigation of long-term deformation events. MTInSAR approaches are indeed applicable to investigate the temporal evolution of ground displacement over time by exploiting coherent (i.e., electromagnetically stable) backscattered points corresponding to reflected elements on the ground. The spread and rapid development of different processing algorithms has permitted wide application to various geohazard fields [6], such as subsidence, landslide, tectonic and volcanic phenomena $[7,8]$.

These InSAR techniques also have certain drawbacks strictly related to the (i) geometrical effects between the LOS (Line of Sight) and the slope; (ii) atmospheric contribution and aliasing phase; and (iii) snow, vegetation, or variable land cover of a target area. Nonetheless, these techniques enable the (i) investigation of wide areas with a high measurement precision; (ii) containing of costs with respect to the benefits [9]; (iii) temporal repetition (up to 6 days over the same area with the Sentinel-1 constellation); (iv) all-weather and day/night operation; (v) investigation of remote and inaccessible areas; and (vi) the possibility to back-analyze a certain phenomenon back to the '90s by using archived satellite data, e.g., ERS1/2 data.

GNSS data play a crucial role in different phases of the InSAR processes since changes in atmospheric refraction can result in a misinterpretation of InSAR results [10]. Specifically, such phases include SAR satellite acquisition, InSAR processing and InSAR post-processing. The GNSS pointwise data can be used for InSAR calibration; Reference Point(s) identification, to which the displacement measured by Persistent Scatterers (PS) is referred; tropospheric and/or ionospheric delay correction [10] or unwrapping the interferometric phase [11] during MTInSAR processing; post-calibration and deformation velocity correction assessed by MTInSAR approaches [12-14]; GNSS deformation measurements comparison with the MTInSAR ground deformation [15]; or MTInSAR product validation by comparison with information derivable by the GNSS network [16]. These are the only possibilities available when attempting to combine the SAR and GNSS datasets taking into consideration the singular analysis of ground deformation.

Indeed, many authors have published interesting works about the combination of InSAR and GNSS data for different purposes, such as (i) atmospheric correction (e.g., [17,18]); (ii) subsidence or uplift analysis (e.g., [9,19]); (iii) tectonic and seismic investigation e.g., [20,21]); (iv) landslide back-analysis (e.g., [22,23]); (v) volcanic event studies e.g., [24,25]); (vi) infrastructure investigation (e.g., [26,27]); (vii) glacial analysis and recognition (e.g., [28,29]); and (viii) other more general applications (e.g., [12,30]).

GNSS data and InSAR are also combined to investigate the atmospheric contribution to InSAR processing with consequences to the velocity and cumulative displacement in the ground deformation analysis [31].

Atmospheric investigation is a complex task due to its heterogeneity. It can be simplified by separately considering the troposphere, approximatively from 0 to $40 \mathrm{~km}$ above the Earth's surface, and the ionosphere, approximatively from 50 to $1000 \mathrm{~km}$. In addition, the troposphere influences the wet lower portion (approximately 0-11 km) and the dry upper layer (approximately $11 \mathrm{~km}$ above the Earth) differently, which can be more difficult and simpler to model, respectively [32]. Considering the wide areas covered by the SAR images, 
e.g., $250 \mathrm{~km}$ with Sentinel-1 [33], the atmospheric effects combined with the reported high precision of the available InSAR approaches could be challenging, especially if the available datasets of SAR images are limited [34,35].

This review focuses on the collection and analysis of scientific contributions that combined GNSS/GPS data and InSAR approaches, i.e., both DInSAR and MTInSAR techniques, for pursuing different perspectives, such as ground deformation recognition and analysis or atmospheric contribution assessment over the entire European continent, excluding Turkey and Russia. In addition, a detailed investigation on Italy, the country most represented by scientific contributions combining GNSS and InSAR data, was conducted. The state-of-theart of the various applications of these two techniques can improve the knowledge of the scientific community and help in the further development of new approaches or additional applications in different fields.

In this review, the DInSAR and MTInSAR approaches were both considered to cover a wider range of field applications, to both rapid and slow phenomena, but analyzing the scientific contribution separately. In contrast, GNSS, GPS, cGPS (continuous GPS), and DGPS (Differential GPS) are considered unique approaches for avoiding discrimination with low statistical soundness considering that the basic approach is the same.

\section{Data Collection}

Data collection was conducted through Google Scholar's freely accessible web search engine to gather a high number of scientific contributions published that considered both InSAR and GNSS/GPS data.

To collect the scientific articles, book chapters and conference abstracts published on the Google Scholar's search engine were based on the following criteria. The first keyword adopted was the name of each European country to which the following two lists of keywords related to GNSS and SAR were connected. For the SAR group, the keywords used were "InSAR" (and related acronyms as "MT-InSAR", Multi Temporal InSAR, "DInSAR", Differential InSAR, or "A-DInSAR", Advanced DInSAR), "PS" (Persistent Scatterers), and "PSI" (Persistent Scatterers Interferometry). For the global absolute measurements, the terms "GNSS" and "GPS" (with related derived names as cGPS) were used.

The use of Google Scholar for this type of research review is considered an appropriate choice, as this search engine can be considered "essentially a superset of WoS and Scopus, with substantial extra coverage" [36]. The same author states that, in Google Scholar, approximately $95 \%$ of the available citations correspond with those contained in the Web of Science (WOS) database and approximately $92 \%$ correspond with those of Scopus in addition to a relevant number of other citations. For this reason, Google Scholar is considered an adapted search engine and a powerful tool for researching the existing literature considering the topic of the combination of GNSS and InSAR data. However, the source of the contributions highlighted by research on Google Scholar has to be validated since this system is less automatized than others, and its database can be completed with information added by the users [37].

The collected scientific contributions, including articles, reviews, book chapters and congress proceedings, were arranged in different folders based on the various searched countries. Then, the contributions were examined iteratively and catalogued in a table considering the following derivable information:

- $\quad$ Title of the scientific contribution;

- $\quad$ List of authors;

- Type of submission (journal, book chapter, conference paper);

- Year of the publication;

- Country;

- $\quad$ Area of interest (province, municipality, local toponym);

- Scale of the presented work (national, regional local);

- $\quad$ Field of application (i.e., Atmosphere, Glacial; Infrastructure, Landslide, Subsidence; Subsidence/Uplift; Tectonic; Uplift; Vulcanic, Other, and Not Specified); 
- $\quad$ Aim of the research;

- Investigated period;

- $\quad$ Type of processing (DInSAR or MTInSAR);

- InSAR approach and algorithm;

- Sensor band;

- Satellite name;

- $\quad$ Data used for the investigation;

- $\quad$ How the two data were used (combination, comparison, validation).

\section{Temporal and Spatial Distribution of Scientific Production in Europe}

3.1. Spatial Distribution

A total of 191 scientific contributions, among which 12 were about the theorical combination of GNSS and InSAR data and 179 focused on the combined techniques, were collected and analyzed considering all European mainlands. Spatially, not all countries have been the subject of combined GNSS and InSAR studies (considering DInSAR or MTInSAR approaches). In fact, 15 European nations, in addition to Gibraltar, Andorra, San Marino, and Vatican City, are not represented by publications regarding the GNSS and InSAR data combination (Figure 1). The higher number of publications have focused on Italy, with 47 contributions divided into 36 journal articles (e.g., [17,27,38-43]), 4 book chapters [44-46], and 7 conference proceedings [47-52]. This number of contributions, which is much higher than that collected for all the other countries, can be justified when considering the high number of geohazards affecting the territory, e.g., landslide events, subsidence phenomena, geothermal processes and mining activities, and the higher use of InSAR within the Italian scientific community.

After Italy, the other nations most represented are as follows: (i) Spain, with 14 articles in peer-reviewed journals (e.g., [53-57]) and 3 congress proceedings [58-60] for a total a 17 scientific contributions; (ii) Germany, with a total number of 15 scientific publications equally divided into various scientific journals (e.g., [61-64]) and conference proceedings (e.g., $[65,66])$; (iii) Portugal, with 8 peer-reviewed scientific articles (e.g., [31,67,68]), 1 book chapter [69], and 3 conference paper (e.g., [70]), and Iceland, represented by 11 contributions in peer-reviewed journals (e.g., [71-73]) and only 1 conference abstract [74], for a total of 12 scientific contribution for both countries; (iv) Norway, with 8 contributions in scientific international journals (e.g., [22,75-77]), 2 book chapters of peer-reviewed journals [78,79], and only 1 proceedings abstract for a conference [80]; and (v) Greece, equally divided in 5 peer-reviewed journal articles (e.g., [81-83]) and 5 abstracts for congresses or meetings (e.g., [84-86]), for a total contribution of 10. It has to be considered that, for the Germany, 11 scientific contributions, i.e., 6 articles published in international peer-reviewed journals and 5 abstracts for congresses refer to the Upper Rhine Graben Area, were focused on the boundary between France and Germany. To avoid repeated counting, it was decided prior to processing to assign all the contributions about the Upper Rhine Graben Area to Germany.

Following the classification, Netherlands is represented by 8 scientific works equally divided into international journal articles and conference papers. Switzerland and Romania provided 7 scientific contributions, 4 peer-reviewed articles, and 3 meeting proceedings, and 5 publications in international journals and 2 extended abstracts, respectively. The United Kingdom is named in 6 scientific works, of which 1 involves the Scotland territory, divided into 4 international peer-reviewed journals and 2 conference proceedings, while France only includes 3 scientific international articles and 1 conference abstract. 


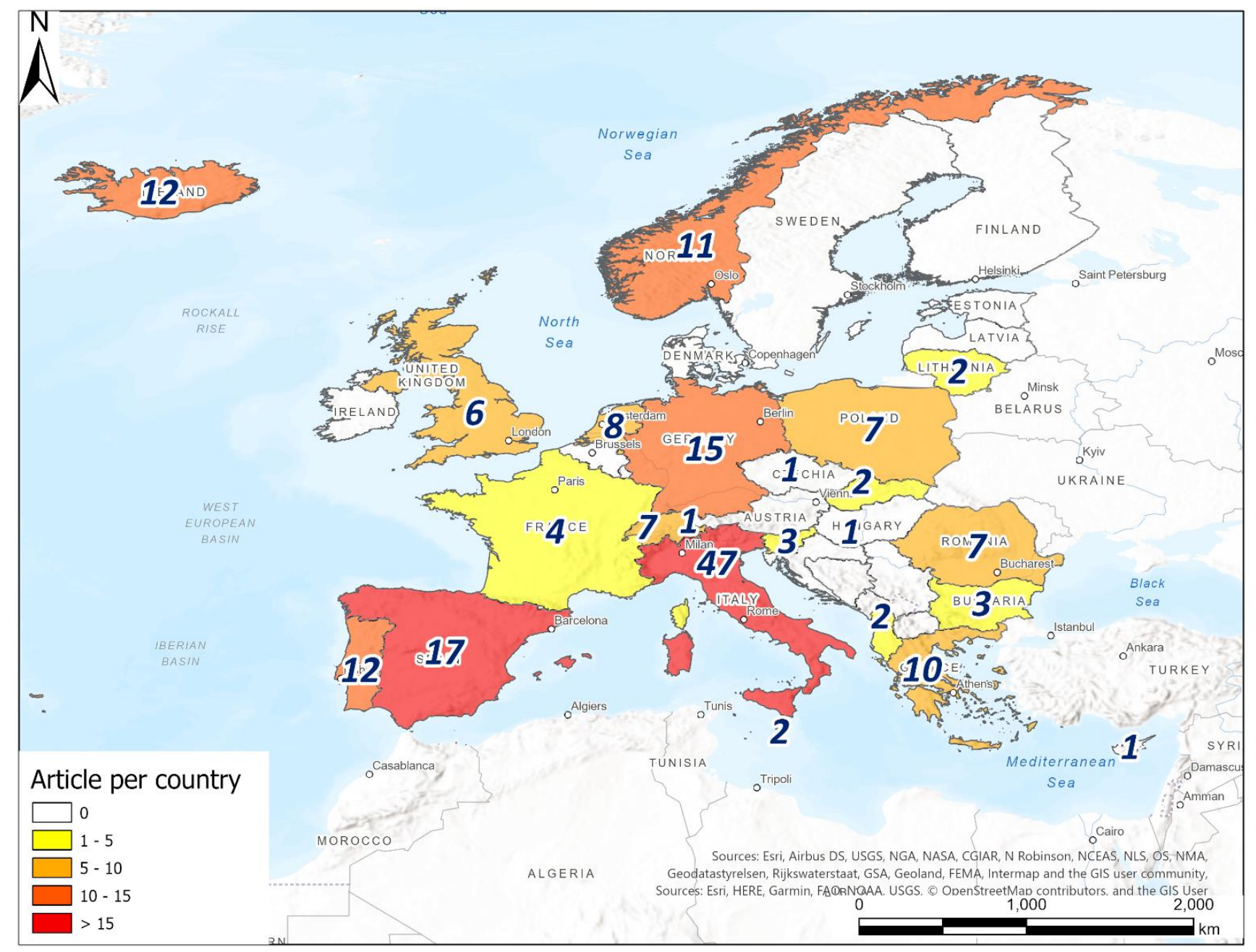

Figure 1. Spatial distribution of the scientific contribution of Europe.

Albania (1 article published in international journal and 1 congress abstract), Lithuania (1 publication in scientific per-reviewed journal and 1 congress abstract), and Slovakia and Malta (two scientific peer-reviewed journals) were represented by 2 scientific contributions, while Liechtenstein, Hungary, Czech Republic, and Cyprus were closely ranked, with only one scientific work.

\subsection{Temporal Distribution}

The first scientific contribution outlining the combined use of GNSS and InSAR data dates back to 1999 [42]. This article focused on a model used to estimate the geometry and slip distribution of the fault plane originating from the 26 September 1997, Colfiorito earthquakes (central Italy) by combining SAR interferometry and GPS measurements. In the following years, since 2000, the scientific community maintained a greater interest in data integration, also involving other European countries, such as Iceland, Spain, and Greece. Since 2009, excluding 2008, with a high number of 8 scientific contributions, a slight increment of scientific contributions was identifiable until 2012, with more than 10 articles, books or conference proceedings. The maximum number of scientific contributions was reached in 2015, with 29 contributions from 14 different countries. Next, in 2018 and 2012, a total of 20 and 17 works were published, respectively. It is worth noting that Italian case studies were published annually, ranging from the first application in 1999 to 2019, only excluding 2009, 2016, and 2020 (Figure 2). 


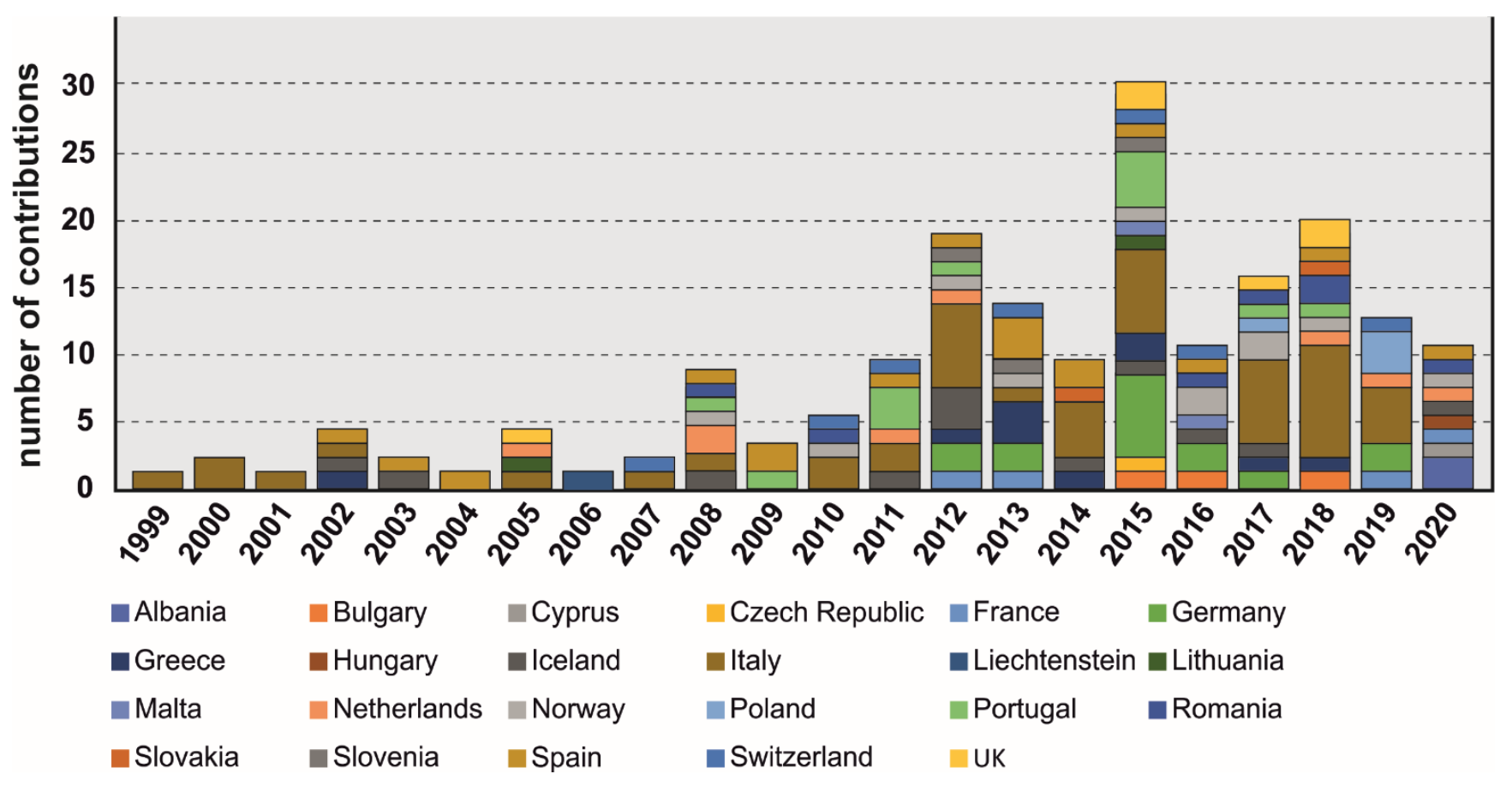

Figure 2. Temporal evolution of the scientific contributions combining GNSS and InSAR data in Europe per country.

The analysis of the temporal evolution in relation to the field of application of scientific contributions (Figure 3) revealed that early studies were focused on the analysis of tectonicinduced deformations. The rise of an anticline beneath an urban area in Catania in 2001 [87] and the modeling of the dislocation of the edifices involved in the 1997 Umbria-Marche seismic sequence [88] were analyzed by integrating GNSS and InSAR data. In 2001, the first atmospheric investigation application was presented, showing primary results regarding the calibration of atmospheric effects on SAR interferograms by GPS and local atmosphere models [38]. In 2002, the joint application of GPS and DInSAR for volcano and seismic monitoring was carried out in different cases in Spain for the 1992-2002 period [55]. In 2005, the first application of the combined use of GNSS and SAR data for recognizing subsidence was published. In particular, five different measurement techniques, among which are the DGPS and MTInSAR approaches, were exploited for mapping and monitoring land subsidence in the Venice lagoon [43]. A year later, the first application to landslide studies was published dealing with the Triesenberg-Triesen landslide in Leichteinstein, where GPS monitoring data were compared with 3D models generated using an MTInSAR approach on ERS datasets [89]. Among the less represented fields of application, in 2002, the first application to glacial research was proposed, where an interferogram was generated to produce an ice surface motion map of the Gjàlp volcano in Vatnajokull, Iceland [29]. Regarding infrastructure and uplift case studies, the first key scientific contribution focused on the monitoring of the urban area of Bratislava, Slovakia [26] and on the investigation of an area close to the geothermal site of Landau, Germany $[19,63]$.

In recent years, the combined use of GNSS and SAR data has been adopted for largescale analyses. Indeed, ground deformation maps have been produced at national scale in the United Kingdom [90] and at continental scale covering all of Europe [91]. In this case, GNSS data were implemented to identify and filter out possible residual atmospheric artefacts that may affect the quality of the employed MTInSAR data. 


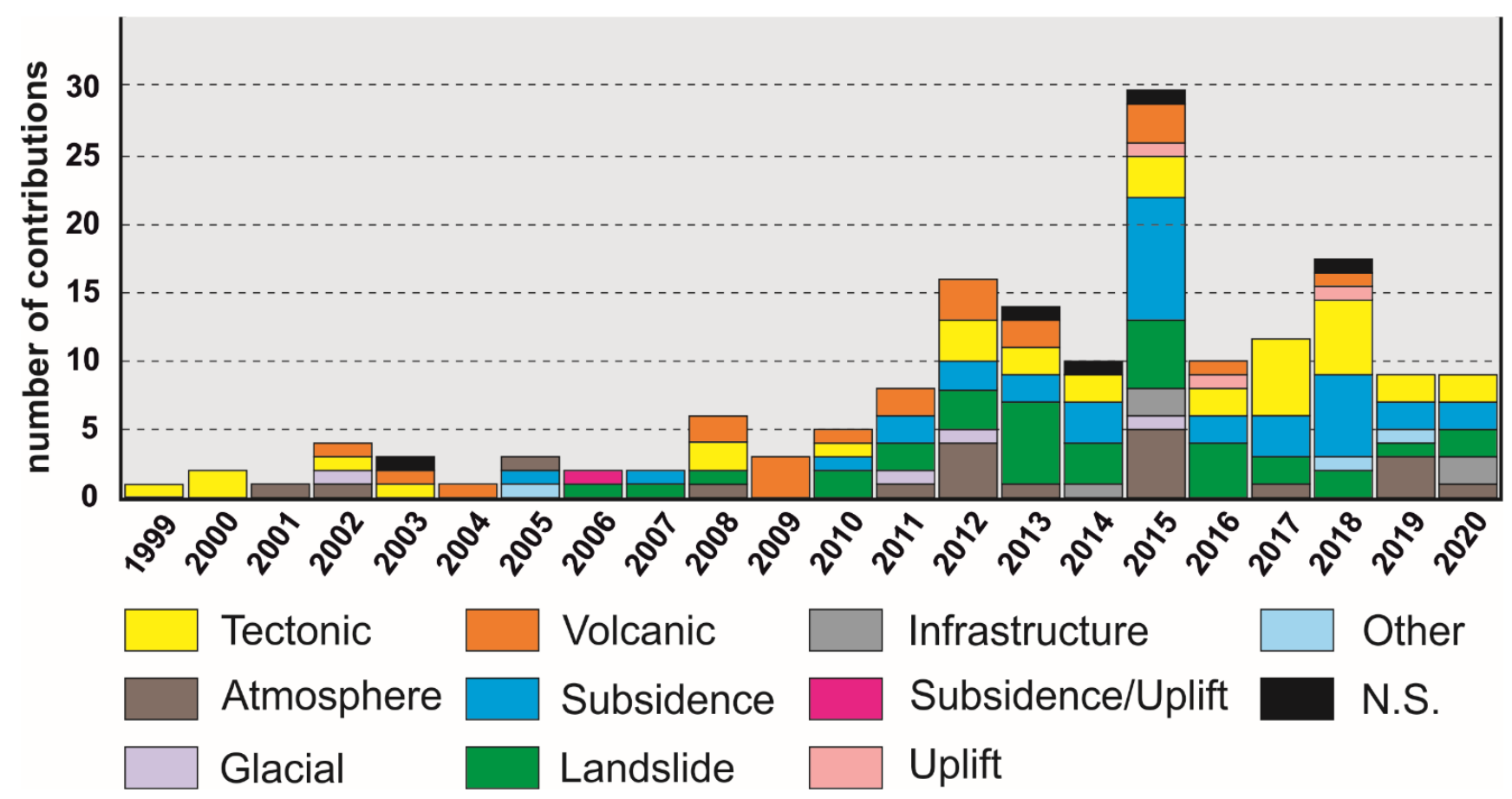

Figure 3. Temporal evolution of the scientific contributions combining GNSS and InSAR data in Europe considering the field of application.

\subsection{Field of Application}

The joint application of SAR and GNSS data has been adopted in 9 different fields, classified as follows: (i) Tectonic; (ii) Atmosphere; (iii) Glacial; (iv) Volcanic; (v) Subsidence; (vi) Landslide; (vii) Infrastructure; (viii) Subsidence/Uplift; and ix) Uplift. In addition, another class has been added to include all nonconventional applications, as well as a Not Specified class (N.S.) for applications in which it was not possible to assign a specific field. A higher percentage of publications deal with subsidence phenomena (20.2\%), followed by landslide events (19.7\%) and tectonic analyses or seismic event back analyses (18.6\%) (Figure 4).

Subsidence phenomena are spatially distributed in Europe, with a higher concentration of studies (i) in the Upper Rhine Graben, at the boundary between France and Germany [62,92-94]; (ii) in Italy, over the Pianura Padana Plain (central Italy), in the Emilia Romagna Region $[44,47,48]$ and the areas of the Po Plain $[20,45,49,95,96]$, in the Venice lagoon $[41,43,97,98]$, in the Friuli Venezia Giulia coastal plain (North-East of Italy) [99], the Firenze-Prato-Pistoia basin (Tuscany Region, central Italy) [100], and the Sibari plain (Calabria Region, South Italy) [101]; and (iii) in Spain, the Alto Guadalentín [102,103] (South-East of Spain), in Lorca town [54] and in the Cardona salt mine [60] (North-East of Spain). In Portugal, instead, only two scientific contributions have been reported in connection to the subsiding area of Lisbon $[70,104]$. Eastern Europe shows a widespread distribution of land subsidence issues, which have been analyzed by combining GNSS and InSAR data, in the coastal portion of Lithuania, close to Kaszuby Lakeland [105], in the agglomeration of Warsaw, Poland [106], in the Bucharest metropolitan area in Romania $[107,108]$, and close to the Tatra Mountains in Slovakia [109]. A specific focus on mining-induced land subsidence events and collapses was provided by research which studied the Upper Silesia Coal basin, covering a part of the territory of Poland [110] and the Czech Republic [111]. North Europe is represented only by the surface motion of peatland in Flow County, Scotland [112], and the localized ground subsidence in the urban settings of London [113] for the United Kingdom and the analysis in the prediction of long-term settlement in the Trondheim harbor, mid-Norway [76]. 


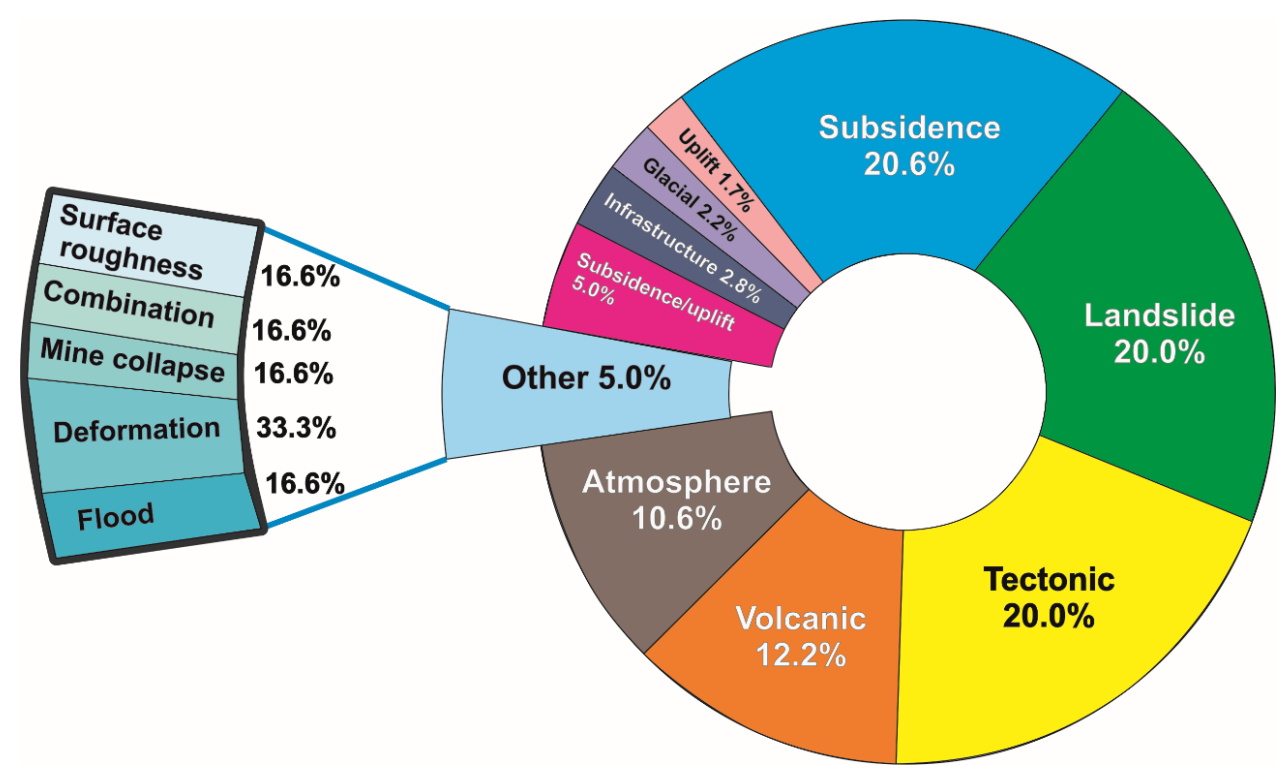

Figure 4. Distribution of the scientific works dealing with the combined use of GNSS and SAR data according to the field of application.

A more widespread distribution of scientific contributions from landslide studies with the joint application of GNSS and SAR data can be observed in Europe. A total of 14 nations have at least one reported application. The country with the highest number of contributions is Norway, represented by the cases of the Ånes landslide [114], the Gamanjunni rock slope [78], the Osmundneset landslide in Sognog Fjordane [115], the periglacial landscape activity at Nordnesfjellet [116], and the mapping [79] and monitoring [80] of landslides in North and West Norway. Norway is followed by Switzerland, with 6 contributions, including 3 peer reviewed articles in international journals and 3 proceedings, which focused on rock glacier detection and monitoring $[117,118]$, slope instability monitoring events in the Western Alps [119,120], and deep-seated landslide recognition by Osco [121] and Aletsch Forest [122]. The third most represented country is Italy, with 5 peer-reviewed articles and a proceeding focus on specific case studies of the Bosmatto landslides in the Northwestern Alps [39], investigations over the wider area of the Northern Apennines [123], and of the Assisi landslides [23,52], in addition to a quantitative hazard and risk assessment of slow-moving landslides in the Arno Basin in Tuscany [124]. Next, there are 4 contributions associated with Spain concerning the monitoring of the Vallcebre landslide [125], the Tena Valley [126,127], which was affected by very slow landslides, and the Portalet landslide area [53]. In Slovenia, 3 works have been dedicated to the deformation monitoring of the Potoška Planina [128-130], while 2 peer-reviewed publications set in Malta deal with slow-moving coastal landslides [131] and landslide susceptibility modeling [132] of the Northwestern coast. Scientific contributions are also found investigating the Triesenberg-Triesen landslide in Liechtenstein [89], the Trifon Zarezan landslide in Bulgary [133], the ground deformation affecting the Choirokoitia UNESCO World Heritage site in Cyprus [134], the La Vallette landslide in France [135], the deformation phenomena that occurred in the Tatra Mountains in Slovakia [109], the ground deformation affecting Kulcs village in Hungary [136], and the investigation of the Grande da Pipa river basin in Portugal [67].

The analysis of tectonic movements (including pre-, sin-, and post-event movements) via GNSS and SAR is mainly concentrated in the seismic areas of Europe. The scientific contributions mainly come from Italy, with 16 publications, Greece and Iceland, with 5, and Romania, with 4 . Italy constitutes a large representation due to the various seismic sequences that have occurred within the last 20 years, such as the 2009 L'Aquila earthquake $[46,137,138]$, the 2012 Emilia Romagna earthquake [139], and the 2016 Central Italy 
seismic swarm [21,50,140-143], in addition to the old 1997 Colfiorito earthquake [42,88]. Furthermore, in Italy, scientific publications on the investigation of the geodynamic processes active throughout the whole Italian territory [20] or focused on the Southeastern Po Plain [144] and the geodynamic movements of the Mount Etna [87] or the strain rate of the Hyblean Plateau [145] in Sicily were developed by exploiting a combination of GNSSand InSAR-derived information. The scientific literature devoted to Greece has reported interesting research on the investigation of pre-earthquake deformation processes by examining GPS, DInSAR, MTInSAR, and ancillary data collected over Zakynthos Island [146]. In addition, the seismological analysis of the critical estimation of a future strong seismic event in the broader area of Cephalonia [82], the post-seismic investigation of a seismic sequence that occurred during the period of January-February 2014 [147] or a specific earthquake, such as the Lefkada involving the Cephalonia Transformation Fault (CTF), close to Cephalonia Island [81], and the post-seismic motion analysis of one of the most active extending grabens, the Corinthian Gulf [85], were collected. Iceland is represented by five contributions. One is the investigation of a $\mathrm{M}_{\mathrm{w}}$ (moment magnitude) 6.5 earthquake that occurred in 2000 [71,148]. The others are on the identification of extensional and interseismic deformation recorded in the Northern Vulcanic Zone [149], as well as the investigation of ground deformation close to geothermal power plants in Hengill due to the interaction of regional tectonics and volcanic deformation [150] and the post-seismic viscous relaxation in the Southern Iceland [151]. In the South Carpatians, Romania, crustal deformation was investigated by detecting small-magnitude tectonic processes [152], and GNSS data, combined with SAR interferometry, were adopted for the analysis of the abnormal seismic behaviors of Izvoarele-Galati and for the development of an early-warning system for marine geohazards along the Black Sea coast [153]. Furthermore, Zoran [154] combined geospatial information, i.e., GPS and SAR images, with in situ information to assess the seismic hazard associated with the Vrancea area in Romania. Other interesting research in the field of tectonism utilized earthquake observations with remote sensing data from the $M_{w} 6.4$ Durres (Albania) earthquake that occurred in 2019 [155] and the $M_{w} 6.5$ Lorca earthquake (Spain) [56]. Studies on seismic [156] and crustal deformation [157], sometimes connected to strain rate analysis [66], or interactions with volcanic systems [68,69], connected to earthquake seismic swarms or active tectonic faults, are more common.

Volcanic (10.9\%) applications are mainly concentrated in (i) Greece, focused on the investigation of Santorini volcano $[158,159]$ and Nisyros volcano $[83,86]$; (ii) Italy, focused on the evaluation of the deformation of Mt. Etna, Sicily Region (Southern Italy) $[160,161]$ and the Campi Flegrei, Campania Region (Southern Italy) [40,51]; (iii) Portugal, focused on the assessment of the geodynamics and displacement mechanisms affecting the Azores islands [13,14,69]; and (iv) Spain [55], focused on the volcanic deformation of the Canary archipelago [58] and Tenerife island $[24,57,162,163]$, inevitably depending on the presence of active volcanoes. Iceland is represented by two scientific articles, one focusing on the lateral dyke grown [72] and the gradual caldera collapse regulated by lateral magma overflow [25] of the Bàrdarbunga stratovolcano in the South-eastern sector of the Iceland island; and a conference paper combining InSAR and GNSS data [74] that focuses on ground deformation measurements of the Northern Volcanic Zone of the island. In addition, Wadge et al. [17] published an article on Mt. Etna focused on the measurement of the tropospheric water value to better consider the contribution of the atmosphere to the differential radar interferograms of ERS1/2.

Atmosphere applications (10.4\%), unlike subsidence, landslide activity, and tectonic and volcanic phenomena, generally involve wide areas, ranging from regional to national scales. Atmospheric applications of the combination of GNSS and SAR data encompass the field of water vapor determination [61,164-169], atmospheric model or delay analysis $[17,18,31,38,170]$, ionospheric artifacts detection [171], atmospheric and wet refractivity reconstruction $[65,172]$ and tropospheric correction or delay [77,173-175], with the final goal of assessing a more precise atmospheric correction in ground deformation analysis of SAR datasets in wide areas or peculiar zones, e.g., volcanic. 
The Subsidence/Uplift class (4.4\%) includes surface deformation analyses performed at a large, regional or national scale, in which both subsidence and uplift phenomena can be identified. Case studies were identified in Netherlands, such as surface deformation analyses performed over the whole national territory [176-179] or monitoring works of the water defence structure of Waddenzee and IJsselmeer [180,181]. Two other scientific contributions focused on the Polish and Lithuanian Baltic coastal areas [105] and the surface displacement pattern affecting the permafrost areas in northern Norway [75].

The categories of Uplift, Infrastructure, and Glacial are poorly represented. In fact, three peer-reviewed articles, focused on the Tower Hamlets Council area of London [182] and on the Geothermal site Landau in Germany $[19,63]$, which only investigated uplift phenomena resulting from the swelling of clayey soil and geothermal consequences, respectively, can be cited. The lower number of studies focused on the investigation of infrastructure can be attributed to several factors, e.g., the resolution of SAR images, the distribution of the GNSS network compared to the infrastructure dimensions, the particularity of the application and the difficulty associated with interpreting the results. An investigation of the nonlinear deformation of infrastructure via SAR data and GNSS comparison was performed in Bratislava, Slovakia [26]. Other infrastructure applications were indirect, including the monitoring of subway construction in Bucharest, Romania [183], ground deformation detection focused on a new geothermal power plant at Reykjanes, Iceland [73], observation of ground deformation associated with the Kozloduy Nuclear Power Plants (NPPs), Bulgary [184], and experimental monitoring of localized deformation on the Roman aqueducts in Rome, Italy [27]. Glacial applications are represented by specific case studies in Iceland, which focused on the 3D surface motion of the glacier surface of the Gjàlp volcano in Vatnajokull [28,29]; France, with a time-series measure of the Argentière glacier on the Mont Blanc Massif [185]; and northern Scotland (United Kingdom) through the investigation of the Glacial Isostatic Adjustment (GIA) [186].

In addition, some very particular studies of the combined use of GNSS and SAR data, categorized as Other (Figure 4), recorded the following: (i) sea level change detection along the coastline of Brest, France [187], along the North Sea and Baltic Sea Coast in Germany [188] and in the Northern Mediterranean Sea [189]; (ii) flood inundation modeling of Northamptonshire [190]; (iii) mine collapse monitoring in Rudna Mine, Poland [191]; (iv) surface and roughness and sediment texture characterization [192]; and (v) a new approach description of precise datum collection [193].

\subsection{Satellite SAR Sensors}

Considering all the aforementioned scientific contributions, whether they are peerreviewed articles, book chapters or conference papers, 32\% of them exploit DInSARbased data, while the remaining $68 \%$ relied on one of the previously described MTInSAR approaches. In detail, more than 100 publications use PSInSAR (Persistent Scatterers Interferometry SAR) data [194], while a minor portion utilized the SPN (Stable Point Network [195]), SqueeSAR [196], SBAS (Small BAseline Subset [197]), iSBAS (Intermittent SBAS [198]), PSP-DINFSAR (Persistent Scatterer Pairs Differential InSAR [199]), CPT (Coherent Pixel Technique [200]), SPINUA (Stable Point Interferometry over Unurbanized Areas [201]), and TSIA (Two-Scale Interferometric Analysis, processing chain that performs a sequence of low-resolution (small-scale) and full-resolution (large-scale) processing [23], based on the SBAS [197] approach) algorithms. It is impossible to establish a precise number of times each algorithm was used since, in some articles, more than one approach was used for different datasets, and in many contributions, the processing algorithm was not clearly specified.

Considering the satellite wavelength of the whole database collected, approximately $150 \mathrm{C}$-band datasets were implemented, as well as $35 \mathrm{X}$-band and $15 \mathrm{~L}$-band datasets. For 15 papers, the $C$ - and $X$-band datasets were combined, while only $7 \mathrm{C}$ - and L-band datasets were used in parallel. None of the scientific studied viewed combined X-and L-bands. Finally, applications analyzing all three bands were implemented 5 times. Publications 
taken into consideration were also categorized according to the satellite constellation of the SAR data. Most of the paper shows a massive application of ENVISAT data (31.1\%), covering the period 2002-2010, and ERS data (27.2\%), covering the period from 1992 to 2000, followed by the data of Sentinel-1 (14.2\%), acquiring SAR images since April 2014, which was largely diffused over the last few years due to its short and constant revisiting time, due to its scientific contribution aim and free availability [33]. All these satellite constellations acquire in the C-band (5.6 cm wavelength), confirming its more widespread use in more common applications as a good compromise for urban and nonurbanized areas. The minor frequencies of other satellites are registered, listed from the high to low: TerraSAR-X (X-band, approximately 10\%), RadarSAT (X-band, approximately 6\%), Alos (L-band, approximately 6\%), and COSMO-SkyMed (X-band, approximately 4.7\%).

Satellite data are also used in combination with others to obtain longer timespans of analysis or to compare the performances of different bands. The combination of different constellation datasets is reported in the satellite graphs of Figure 5. It is interesting to note that, in at least one paper, all constellation satellites were combined with the other three constellations, except for RadarSAT, which did not show application when combined with the other 3 datasets. In addition, it is possible to state that the aforementioned constellation satellites are rarely combined with the other two and commonly with other datasets. Exceptions are also detectable for the COSMO-SkyMed, X-band, and Alos, L-band, whose data were more often used combined with two other constellations than standalone or only with one other dataset.

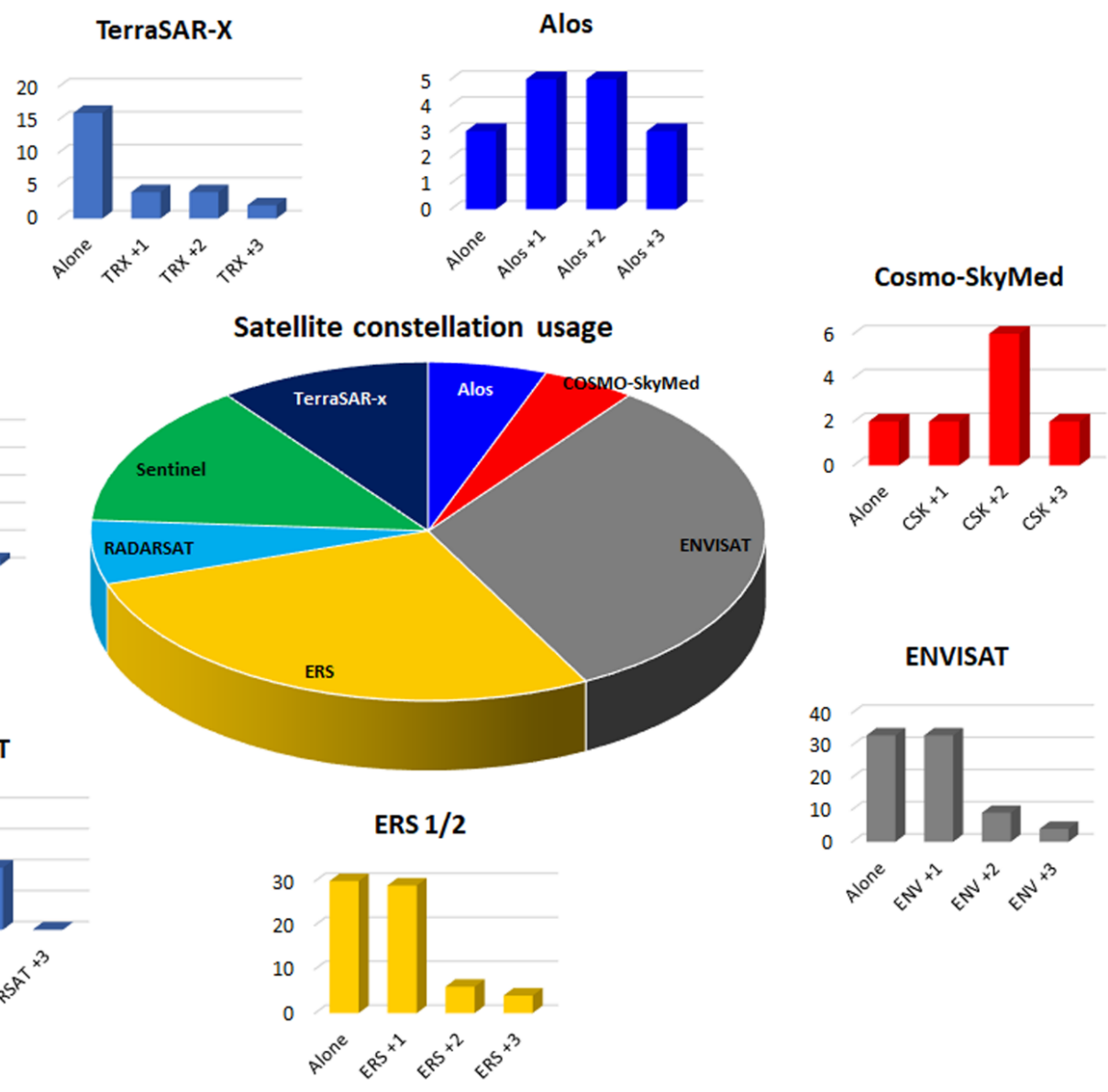

Figure 5. Satellite constellation usage considering all the applicative scientific contributions (center) and a more detailed analysis of the use of the dataset of a single satellite (Alone) or with another satellite $(+1)$, with other $2(+2)$ or three $(+3)$ constellations (satellite graphs). 


\section{Temporal and Spatial Distribution in Italy}

A more specific analysis of the temporal and spatial distribution of previous studies, as well as within the field of application, was conducted focusing on the Italian literature, since Italy is the most represented country, accounting for the 47 published scientific contributions on the integrated use of GNSS and InSAR data.

The highest number of scientific contributions is recorded in Emilia-Romagna and Umbria, which are two regions where tectonic, seismic, subsidence, and landslide events were analyzed (Figure 6).

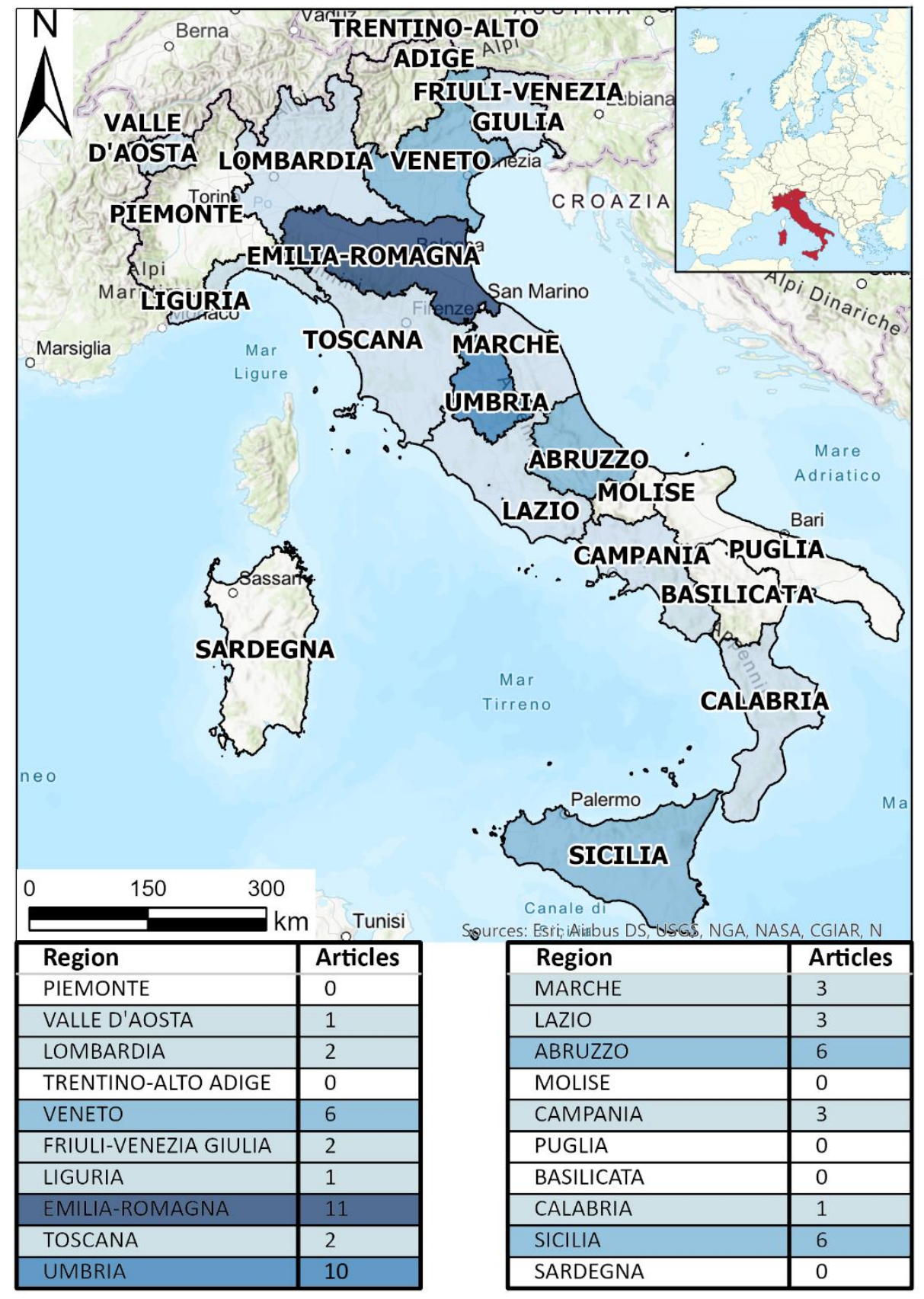

Figure 6. Spatial distribution per region in Italy.

Despite the higher number of articles, books, and conference proceedings with case studies performed over the Italian territory, not all the regions are covered. In fact, six Italian regions do not exhibit any phenomena investigated by either GNSS or SAR data. One article [20] took into consideration the entire Italian territory using both techniques 
to study Earth surface deformation to provide the displacements with respect to different ground point position components.

In the Valle d'Aosta Region, in Northwestern Italy, a large landslide in a high alpine environment was studied by GNSS, InSAR, and GB-InSAR remote sensing data to reduce uncertainties. The joint combination of these techniques provided a comprehensive view of the deformation field of the landslide [39].

Landslide investigations are also identified in the Umbria Region, central Italy, for the analysis and monitoring of the slow-moving Assisi landslide [23,52]. The geodetic and interferometric products of four deep-seated landslides reactivated by the excavation of a double road tunnel that induced deformation were monitored in the Northern Apennine [123], while the same type of data was used in the Arno River basin, Tuscany Region, to update previous hazards and risk map realized by [124], Catani, et al. [202].

The highest number of applications, 15 in total, is represented by subsidence phenomena investigations. Seven scientific contributions on this theme, i.e., 2 peer-reviewed articles, 2 book chapters, and 3 conference proceedings, target the Emilia-Romagna Region, central Italy, 4 of which are specifically on the Po Plain. Only one is focused on the Tuscany Region, central Italy, more specifically in the Firenze-Prato-Pistoia Plain [100], as one on the Sibari Plain in the Calabria Region, South Italy [101], and on the plain that lies between the Tagliamento and Isonzo Rivers in the Friuli-Venezia Giulia Region, North-East of Italy [99]. The remaining 5 scientific contributions focus on the vertical deformation of the Venice lagoon $[41,43,97,98]$ or, more generally, on the subsidence phenomenon affecting the North Adriatic Sea [45].

The high number of scientific contributions sourced from the Umbria Region, central Italy, resulted from the Assisi landslide analysis and monitoring, as well as the investigation of the earthquakes that occurred in 1997, 2009, and 2016 involving Umbria and the neighboring regions. In total, 16 contributions targeted the investigation of tectonic and seismic investigations.

In contrast to the landslide or subsidence investigations, the seismic analyses typically involved more than one region as earthquakes affect larger regions. For this reason, 4 articles and one conference proceeding focus on more than one region of central Italy. The 2009 L'Aquila earthquake, Abruzzo Region, was also represented in an article and in a book chapter analyzing the coseismic rupture [46] and slip distribution [138] concentrating the study area close to the epicenter. The 2012 Emilia-Romagna Region, instead, did not have relevant effects on the boundary regions. One of these contributions addresses the modeling of the influence of fluids and pore-pressure changes on surface displacements and on the Coulomb Failure Function (CFF) in the co-seismic and post-seismic period related to the 2012 mainshock [139]. Wang et al. [142] looked for the source parameters and triggering link between the earthquake sequences of 2009 and 2016 recorded in central Italy. In addition, 4 works combining InSAR and GNSS data were developed for determining the source parameter of the three main shocks recorded during the 2016 Central Italy earthquake sequence $[50,140]$, for a modern observation of the spatio-temporal evolution of the seismic sequence [143] and for a novel record of near-field co-seismic fault slip measurement [21].

The spatial distribution of 5 volcanic scientific contributions, including 4 journal articles and one symposium proceeding, is strictly related to the location of volcanic cones in Italy. In fact, 3 publications focus on the analysis of nonlinear deformation [51], the evaluation of fault reactivation [203] and the investigation of magma injection [204] of the Campi Flegrei, Campania Region, and two on the ground deformation pattern of the Mt. Etna volcano in Sicily $[160,161]$.

The Mt. Etna volcano is also the subject of two peer-reviewed articles investigating the varied tropospheric compensation expectations between the GPS and SAR interferograms [38] and the dynamic models of atmospheric movement for calculating the delays affecting radar processing [17]. The other area where the atmospheric delay analysis was undertaken was centered over the Como province in Lombardia Region, North Italy, 
presenting the results in an international scientific journal [18] and in an international symposium [170].

In conclusion, the Italian territory has been a relevant case study since 1999 [42], and it was continuously under investigation by the scientific community until 2019 that analyzed both GNSS and SAR data for different purposes (Figure 7).

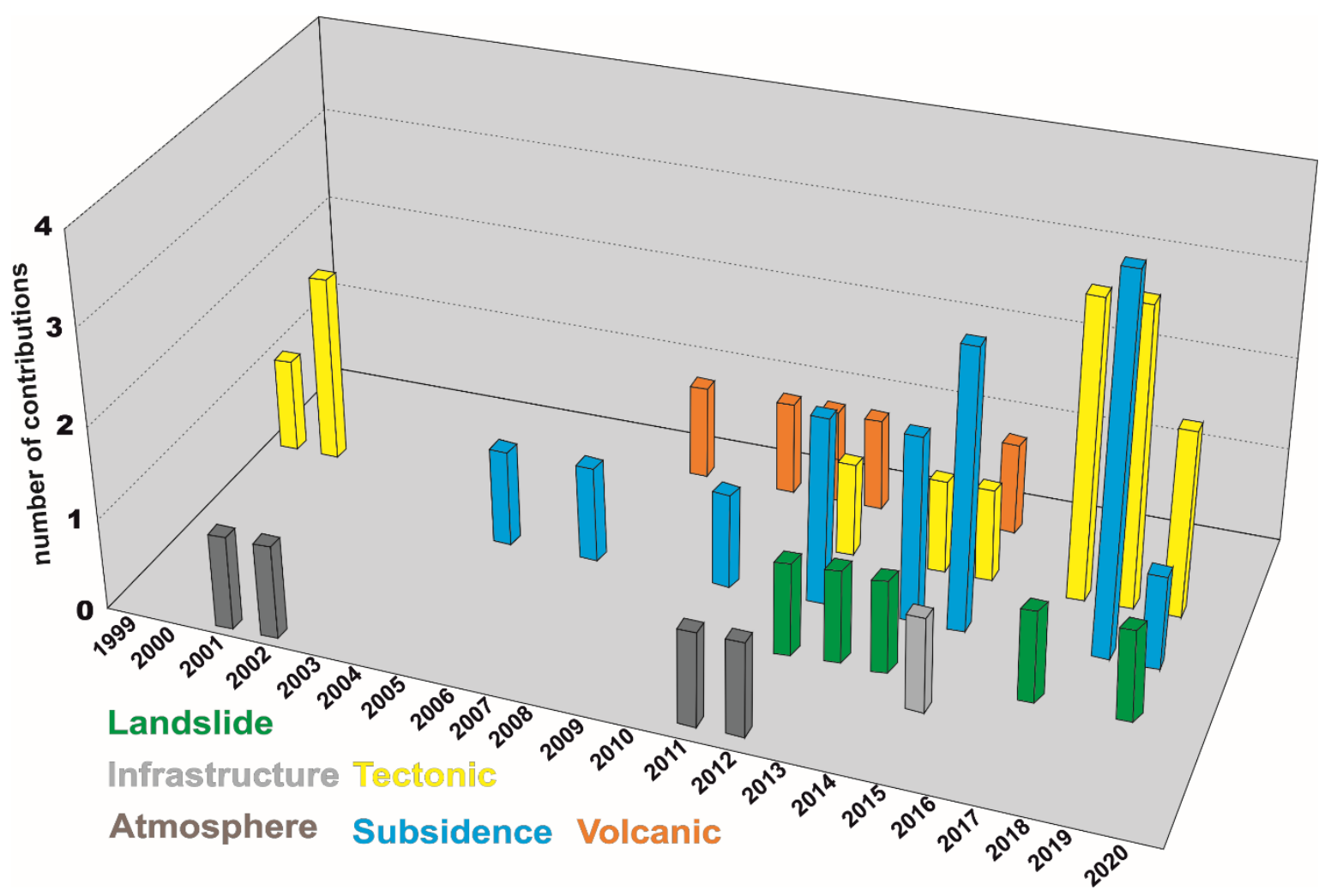

Figure 7. Temporal distribution of the scientific contribution recorded in Italy categorized according their field of application. Scientific contributions are missing for 2003, 2004, 2006, 2009, 2016, and 2020.

\section{Discussion}

A substantial number of scientific contributions using remote sensing data derived from GNSS and SAR systems to investigate and analyze ground deformation in European countries, covering a time span of 31 years (from 1999 to 2020), were collected.

The spatial distribution of all the scientific contributions, considering scientific articles, book chapters or conference proceedings, mirrors the distribution of the main relevant geohazards affecting each country. Italy and Spain are well represented due to the high number of geohazards affecting their territory, especially considering the subsidence occurring in both Italy [205] and Spain [9] and the landslides affecting Italy [206]. The limited number of scientific contributions combining GNSS and InSAR data to study landslides is surprising considering the relevance of these natural hazards and the major consequences occurring throughout Europe [207]. Nonetheless, the Italian territory is also affected by frequent seismic swarms and strong earthquakes in addition to the presence of volcanoes, and both phenomena are deeply investigated by the joint use of GNSS and SAR data. In the same way, it is surprising how low the number of applications recorded in the Netherlands is considering the importance of subsidence phenomena in that country (e.g., [208]), which exert social and economic consequences and induce damage to structures and infrastructure [209,210]. Another well-represented nation is Norway, which is strongly affected by landslides, often triggered in quick clay soils [211], and characterized by the presence of permafrost, which can cause four types of landforms [212]: (i) palsas (e.g., [213]), 
(ii) rock glaciers (e.g., [214,215]), (iii) ice-cored moraines (e.g., [214,216]), and (iv) ice-wedge polygons (e.g., [217]).

In addition to scientific papers dedicated to the analysis of displacement, general articles employing atmospheric analyses, in which GNSS products are implemented to correct interferograms or remove the geodetic influence on InSAR displacement measurements over wide areas, were collected and analyzed. This approach is even more relevant due to the nature of the wide areas investigated and monitored by InSAR approaches.

The combination of DInSAR and GNSS data has not always been categorical, but various trends and approaches utilized over the years can be illustrated.

The various works analyzed have shown the potential of combining both data for different purposes. For instance, GNSS data were used to improve the accuracy of the interferograms generated [11], topographically correcting the interferograms and the elevation data to measure ice surface motion maps along the Gjalp Volcano. Most of the works jointly used GNSS and DInSAR data to produce a more precise and reliable analysis of the movements detected by either combining or validating the available data. Indeed, in most of the pioneering works, authors worked to validate DInSAR data, since in most of the cases, the latter were used for the first time and their results needed to be validated. For instance, in Raucoules et al. [135], in which 3D data derived from TerraSAR-X processing over the La Vallette landslide (southern France) were validated with GNSS data; in other cases, such as in Bovenga et al. [23] and Sakkas et al. [146], GNSS data, along with geological and geotechnical data, were used to ground truth C- and X-band imagery.

Approximatively half of the scientific works are focused on single case studies or events with a local influence, while $45 \%$ involve regional areas. Temporally, more recent papers involve more large areas due to various factors: (i) the possibility to have more and improved algorithms for processing large SAR datasets; (ii) the technological progress of the last few years, allowing us to have available advanced computational resources, e.g. cloud computing by virtual machine system and parallel or distributed computing architectures used to process larger dataset over wide areas; (iii) the willingness of different radar satellite constellations, also in different bands, i.e., X-band, C-band and L-band; and (iv) the ease of obtaining free SAR images at a medium resolution, such as the Sentinel-1 constellation, by the Copernicus Access Hub of the ESA (European Space Agency), ensuring systematic worldwide covering acquisition since April 2014, or the availability of limited imagery datasets at a high resolution, i.e., $X$-band, by means of dedicated scientific projects in open calls. Only a few articles, 10 of the 174 examined, have as a main aim the analysis of more case studies in the same nation, within very wide areas, or throughout entire countries. In detail, four articles are noteworthy for the extension and the relevance of the work. The first two focused on the ground deformation occurring in Netherlands [176,178], while the remaining focus on the generation of atmosphere Precipitable Water Vapor (PWV) maps over large areas in Portugal [169] and the feasibility assessment of a national InSAR ground deformation map over the United Kingdom [90], which both took place in 2017. In 2020, the first continental-scale processing of Sentinel-1 imagery was described in Lanari et al. [91], which provided a calibrated ground deformation map of Europe with the velocity of deformation and cumulative displacement corrected by the GNSS network data.

The authorship, taking into account the affiliation of the first author of the scientific contributions on ground deformation or atmosphere contribution analyses over European countries, demonstrates that approximately $80 \%$ of the total refers to the same nations. For the remaining approximately $20 \%, 10$ authorships are referred to Countries outside of Europa (e.g., 4 from USA, 5 from China, and 1 from Canada), while the other main authorships are of Italian (8), Portugal (6), and French (5) researchers. This can be justified by considering (i) collaborations or (ii) projects from different universities, institutions, or entities and (iii) the $\mathrm{PhD}$ abroad periods or (iv) research abroad time of researchers. Italy, with 9 contributions authored by non-Italian investigators, is the most investigated nation, not only by Italian researchers but also those from European (2) and international (5) investigators. Next, Portugal is unique in that it was only analyzed by Portugal researchers that 
also investigate Romania (6 contributions to 7 are from Portugal researchers), followed by Spain, with 5 contributions from European researchers.

The correlation between the temporal evaluation of European and Italian studies is interesting. For the first few years, this relation is easily comprehensible considering that the scientific contribution collected for the first three years, i.e., 1999-2000 and 2001, involved the Italian territory. It is interesting to note, comparing Figures 2 and 7, that the trend is very similar, with an incremental increase that progressed until the peak contribution in 2015, which was then followed by a reduction. The high number of scientific contributions recorded over the Italian territory severely influences the trend of the temporal distribution that occurred over Europe. In contrast, the studies published in 2020 do not follow this role; in fact, the last analyzed year exhibits a relevant number of scientific contributions of 2019 even if no publications were published involving Italy. A similar correlation can also be identified when considering the European and Italian temporal distributions and the associated field of application.

Combining the information regarding the year of publication of the scientific contributions collected and the investigated SAR satellite, it is possible to state that the later publications aimed to investigate the evolution of a phenomenon as long as possible. Obviously, this cannot be affirmed for publications involving atmospheric interactions and corrections or for those investigating the co-seismic earthquake effects of DInSAR.

The incremental increase in the number of publications reported demonstrates that the remote sensing techniques investigated in this review, i.e., geodetic and InSAR approaches, were being readily employed by the scientific community as a result of their benefits and the consequences for stakeholders and end-users as environmental managers. In recent years, this interest began to be traduced in the publication of national and regional GMS (Ground Motion Services) due to the free availability of InSAR data and, in some cases, the already GNSS-calibrated model. In fact, a higher number of applications, and thus a greater number of papers, was collected and recorded in those countries in which a Ground Motion Service (GMS) already exists or is nearly ready for presentation. In 2002, Italian law allocated funds for a Not-ordinary Plan of Environmental Remote Sensing aiming at monitoring considered at risk hydro-geomorphological areas, providing nationwide ground deformation maps calibrated by GNSS data. ERS and ENVISAT interferometric products, processed by PSInSAR and PSP-DINSFAR approaches, were published in the first phase of the project (2008-2009) and then updated in a second phase (2010-2011), while COSMO-SkyMed data were implemented in the same project in the third and final phases (2013-2015) [218,219]. Next, the first nation that made available updated GMS data over the entire territory was Norway in 2018; this publication was provided by the WebGIS portal Radasat-2 data (2010-2018) and Sentinel-1 (2015-2019), not calibrated by GNSS information [220]. In 2019, a year later, BodenBewegungsdienst Deutschland presented the Germany GMS, making the Sentinel-1 PS data available, GNSS-calibrated, processed thanks to the PSI approach [221] by the DLR German Aerospace Center research institute. In addition, Danish GMS and Dutch GMS are under development and will be published soon. More locally, Tuscany (central Italy) and Veneto Region (North-East Italy) have produced regional GMSs that are providing Sentinel-1 MTInSAR data free of charge processed by the SqueeSAR [196] algorithm. These three regions are the object of continuous monitoring, which is systematically updated and interpreted every 12 days. In addition, the application of a data-mining algorithms also highlight the PS with relevant trend changes [222,223]. Taking into account the usefulness and versatility demonstrated by this review regarding the combination of GNSS and InSAR data in ground deformation analysis, in the future, PS data will become available, and the national and regional GMS should be GNSS-calibrated. Currently, this procedure is sometimes conducted by researchers as a further step for specific investigations with good results [20,100].

Consequently, the promising results obtained by the scientific community and the free availability of data, which permit drastic cost reductions, have drawn increasing interest 
from the administrative managing office for the mapping and monitoring of the ground deformation issue [223-225].

In addition, since 2016, Europe has been working on an initiative pushing to implement the available data provided by MTInSAR products at continental scale in a project named European Ground Motion Service (EGMS) [226]. The three main products provided by the EGMS are: (i) the ground deformation maps and time-series along the LOS direction; (ii) an advanced ground deformation map in LOS direction combined with the GNSS data of the EUREF permanent network (EPN) [227]; and (iii) the two main deformation components derivable from the combination of the two orbits, i.e., the horizontal East-West and the vertical up-down deformation. All these products will be updated annually and will open several other opportunities for investigation with a consequent advancement in the knowledge in various fields, e.g., ground deformation prediction [228], mapping [224,225,229], and monitoring [230] of natural hazards, and atmospheric delay analysis.

Another use of GNSS data, which has become increasingly widespread over recent years, is aimed at the retrieval of 3D surface displacement, thus overcoming the limitations associated with DInSAR LOS displacement measurements, e.g., References [92,128]. Some limits of the geodetic and InSAR approaches can be overcome by the combination of GNSS and InSAR data, but some limitations cannot be removed. In the latest year, GNSS data were mostly used for completing SAR-derived information and filling in points were data were missing, thus improving the temporal coverage of the deformation time series, as performed in a pervious study [100], or for investigating the "real" ground deformation velocity, thereby remedying the geodetic displacement that affects the ordinary InSAR measurements. Furthermore, the areal coverage of results can be improved by joining GNSS stations and derived-PS points by PSI approaches, which can obtain deformation data over areas invisible to SAR systems, e.g., Reference [39]. It enables the obtainment of information in areas that are not covered by direct measurements or by the use of a single technique. On the other hand, GNSS stations are placed in strategic positions to create an approximatively regular network and cannot completely overpass the InSAR limits, such as the coverage of shadow areas due to the interaction between the topography and the LoS of SAR satellites. To overcome this limitation, a traditional survey with an operator by GPS must be conducted, reducing the easy and fast repeatability and considerably enlarging the time and monetary expenses.

The substantial improvement of both technical and technological approaches in recent decades, as well as the demonstrated useful and versability of the combination of GNSS and InSAR remote sensing techniques for different purposes, by more than 180 scientific contributions suggests that the incremental use of these approaches in the future will be further enhanced and widespread. The free availability of Sentinel-1 images and InSAR products by GMS will help in the increasing application in different fields and the relative spreading and dissemination.

\section{Conclusions}

A review of the published scientific contributions that focused on the European continent, excluding Turkey and Russia, combining GNSS (Global Navigation Satellite System) and InSAR (Interferometric Synthetic Aperture Radar) data, is reported here. A total of 191 scientific contributions were collected and analyzed in detail. The high number of contributions includes peer-reviewed articles and book chapters published in international journals, as well as the abstracts, conference proceedings, and extended abstracts of national and international congresses and symposiums.

An analysis of the spatial and temporal distribution of the scientific contributions was completed for Europe, while a specific focus was dedicated to Italy, since it is the most represented country, with 47 scientific contributions. Italy is also the first nation that reported a study combining GNSS and InSAR data. In fact, the first research work was recorded in 1999 and investigated the geometry and slip distribution of the fault plane originated Colfiorito earthquakes (central Italy), occurred on 26 September 1997. 
Most of the joint applications in Europe, as also recognizable for Italy, focus on landslide, subsidence, and seismic/tectonic case studies. The spatial distribution mostly corresponds to the distribution of geohazards in Europe, e.g., subsidence phenomena investigated in Netherlands and volcano case studies in southern Italy, Iceland, and Spanish islands.

Considering the free access of InSAR data by Ground Motion Services (GMS), a good correspondence can be recognized. This research is interesting since it is a good demonstration that the scientific community and administrative managing offices are interested in the remotely sensed analysis of ground deformation. This can be a good starting point for the continued development of improvements in this branch of remote sensing research and in the free accessibility of data policy. Scientific advancement by the scientific community, and consequently the local administrator and the entire population, could receive a great benefit from open access data both from the perspective of research and in confidence in the products.

Author Contributions: Conceptualization and writing, M.D.S.; bibliographic review and creation of the database, M.D.S., P.S., and P.C.; methodology and figures preparation, M.D.S. and P.C.; review and homogenization, S.B. and N.C. All authors have read and agreed to the published version of the manuscript.

Funding: This research received no external funding.

Conflicts of Interest: The authors declare no conflict of interest.

\section{References}

1. Graham, L.C. Synthetic interferometer radar for topographic mapping. Proc. IEEE 1974, 62, 763-768. [CrossRef]

2. Zulkifli, N.A.; Din, A.H.M.; Som, Z.A.M. Vertical land motion quantification using space-based geodetic methods: A review. In Proceedings of the IOP Conference Series: Earth and Environmental Science, Kuala Lumpur, Malaysia, 24-25 April 2018; p. 012024.

3. Bruyninx, C.; Legrand, J.; Fabian, A.; Pottiaux, E. GNSS metadata and data validation in the EUREF Permanent Network. GPS Solut. 2019, 23, 1-14. [CrossRef]

4. Gabriel, A.K.; Goldstein, R.M.; Zebker, H.A. Mapping small elevation changes over large areas: Differential radar interferometry. J. Geophys. Res. Solid Earth 1989, 94, 9183-9191. [CrossRef]

5. Crosetto, M.; Monserrat, O.; Cuevas-González, M.; Devanthéry, N.; Crippa, B. Persistent scatterer interferometry: A review. ISPRS J. Photogramm. Remote Sens. 2016, 115, 78-89. [CrossRef]

6. Tomás, R.; Li, Z. Earth Observations for Geohazards: Present and Future Challenges. Remote Sens. 2017, 9, 194. [CrossRef]

7. Zhou, X.; Chang, N.-B.; Li, S. Applications of SAR interferometry in earth and environmental science research. Sensors 2009, 9, 1876-1912. [CrossRef] [PubMed]

8. Pepe, A.; Calò, F. A review of interferometric synthetic aperture RADAR (InSAR) multi-track approaches for the retrieval of Earth's surface displacements. Appl. Sci. 2017, 7, 1264. [CrossRef]

9. Tomás, R.; Romero, R.; Mulas, J.; Marturià, J.J.; Mallorquí, J.J.; Lopez-Sanchez, J.M.; Herrera, G.; Gutiérrez, F.; González, P.J.; Fernández, J. Radar interferometry techniques for the study of ground subsidence phenomena: A review of practical issues through cases in Spain. Environ. Earth Sci. 2014, 71, 163-181. [CrossRef]

10. Hanssen, R.F.; Weckwerth, T.M.; Zebker, H.A.; Klees, R. High-resolution water vapor mapping from interferometric radar measurements. Sci. Environ. 1999, 283, 1297-1299. [CrossRef]

11. Gudmundsson, S.; Carstensen, J.M.; Sigmundsson, F. Unwrapping ground displacement signals in satellite radar interferograms with aid of GPS data and MRF regularization. IEEE Trans. Geosci. Remote Sens. 2002, 40, 1743-1754. [CrossRef]

12. Simonetto, E.; Durand, S.; Burdack, J.; Polidori, L.; Morel, L.; Nicolas-Duroy, J. Combination of INSAR and GNSS measurements for ground displacement monitoring. Procedia Technol. 2014, 16, 192-198. [CrossRef]

13. Catalão, J.; Nico, G.; Hanssen, R.; Catita, C. Integration of InSAR and GPS for vertical deformation monitoring: A case study in Faial and Pico Islands. In Proceedings of the Fringe 2009 Workshop, Frascati, Italy, 30 November-4 December 2009 ; pp. 1-7.

14. Catalão, J.; Nico, G.; Hanssen, R.; Catita, C. Merging GPS and atmospherically corrected InSAR data to map 3-D terrain displacement velocity. IEEE Trans. Geosci. Remote Sens. 2011, 49, 2354-2360. [CrossRef]

15. Samsonov, S.; Tiampo, K. Analytical optimization of a DInSAR and GPS dataset for derivation of three-dimensional surface motion. IEEE Geosci. Remote Sens. Lett. 2006, 3, 107-111. [CrossRef]

16. Lee, I.; Chang, H.-C.; Ge, L. GPS campaigns for validation of InSAR derived DEMs. J. Glob. Position. Syst. 2005, 4, 82-87. [CrossRef] 
17. Wadge, G.; Webley, P.; James, I.; Bingley, R.; Dodson, A.; Waugh, S.; Veneboer, T.; Puglisi, G.; Mattia, M.; Baker, D. Atmospheric models, GPS and InSAR measurements of the tropospheric water vapour field over Mount Etna. Geophys. Res. Lett. 2002, $29,1905$. [CrossRef]

18. Cheng, S.; Perissin, D.; Lin, H.; Chen, F. Atmospheric delay analysis from GPS meteorology and InSAR APS. J. Atmos. Sol. Terr. Phys. 2012, 86, 71-82. [CrossRef]

19. Heimlich, C.; Gourmelen, N.; Masson, F.; Schmittbuhl, J.; Kim, S.-W.; Azzola, J. Uplift around the geothermal power plant of Landau (Germany) as observed by InSAR monitoring. Geotherm. Energy 2015, 3, 1-12. [CrossRef]

20. Farolfi, G.; Piombino, A.; Catani, F. Fusion of GNSS and Satellite Radar Interferometry: Determination of 3D Fine-Scale Map of Present-Day Surface Displacements in Italy as Expressions of Geodynamic Processes. Remote Sens. 2019, 11, 394. [CrossRef]

21. Wilkinson, M.W.; McCaffrey, K.J.; Jones, R.R.; Roberts, G.P.; Holdsworth, R.E.; Gregory, L.C.; Walters, R.J.; Wedmore, L.; Goodall, H.; Iezzi, F. Near-field fault slip of the 2016 Vettore M w 6.6 earthquake (Central Italy) measured using low-cost GNSS. Sci. Rep. 2017, 7, 1-7. [CrossRef]

22. Lauknes, T.; Shanker, A.P.; Dehls, J.; Zebker, H.; Henderson, I.; Larsen, Y. Detailed rockslide mapping in northern Norway with small baseline and persistent scatterer interferometric SAR time series methods. Remote Sens. Environ. 2010, 114, 2097-2109. [CrossRef]

23. Bovenga, F.; Nitti, D.O.; Fornaro, G.; Radicioni, F.; Stoppini, A.; Brigante, R. Using C/X-band SAR interferometry and GNSS measurements for the Assisi landslide analysis. Int. J. Remote Sens. 2013, 34, 4083-4104. [CrossRef]

24. Fernández, J.; Yu, T.-T.; Rodrıguez-Velasco, G.; González-Matesanz, J.; Romero, R.; Rodrıguez, G.; Quirós, R.; Dalda, A.; Aparicio, A.; Blanco, M. New geodetic monitoring system in the volcanic island of Tenerife, Canaries, Spain. Combination of InSAR and GPS techniques. J. Volcanol. Geotherm. Res. 2003, 124, 241-253. [CrossRef]

25. Gudmundsson, M.T.; Jónsdóttir, K.; Hooper, A.; Holohan, E.P.; Halldórsson, S.A.; Ófeigsson, B.G.; Cesca, S.; Vogfjörd, K.S.; Sigmundsson, F.; Högnadóttir, T. Gradual caldera collapse at Bárdarbunga volcano, Iceland, regulated by lateral magma outflow. Science 2016, 353, 6296. [CrossRef]

26. Bakon, M.; Perissin, D.; Lazecky, M.; Papco, J. Infrastructure non-linear deformation monitoring via satellite radar interferometry. Procedia Technol. 2014, 16, 294-300. [CrossRef]

27. Tapete, D.; Morelli, S.; Fanti, R.; Casagli, N. Localising deformation along the elevation of linear structures: An experiment with space-borne InSAR and RTK GPS on the Roman Aqueducts in Rome, Italy. Appl. Geogr. 2015, 58, 65-83. [CrossRef]

28. Magnússon, E.; Björnsson, H.; Rott, H.; Roberts, M.J.; Pálsson, F.; Guđmundsson, S.; Bennett, R.A.; Geirsson, H.; Sturkell, E. Localized uplift of Vatnajökull, Iceland: Subglacial water accumulation deduced from InSAR and GPS observations. J. Glaciol. 2011, 57, 475-484. [CrossRef]

29. Gudmundsson, S.; Gudmundsson, M.T.; Björnsson, H.; Sigmundsson, F.; Rott, H.; Carstensen, J.M. Three-dimensional glacier surface motion maps at the Gjálp eruption site, Iceland, inferred from combining InSAR and other ice-displacement data. Ann. Glaciol. 2002, 34, 315-322. [CrossRef]

30. Ge, L. Integration of GPS and radar interferometry. GPS Solut. 2003, 7, 52-54. [CrossRef]

31. Mateus, P.; Nico, G.; Tomé, R.; Catalão, J.; Miranda, P.M. Experimental study on the atmospheric delay based on GPS, SAR interferometry, and numerical weather model data. IEEE Trans. Geosci. Remote Sens. 2012, 51, 6-11. [CrossRef]

32. Spilker, J., Jr. Tropospheric effects on GPS. Glob. Posiotioning Syst. Theory Appl. 1996, 1, 517-546.

33. Torres, R.; Snoeij, P.; Geudtner, D.; Bibby, D.; Davidson, M.; Attema, E.; Potin, P.; Rommen, B.; Floury, N.; Brown, M. GMES Sentinel-1 mission. Remote Sens. Environ. 2012, 120, 9-24. [CrossRef]

34. Gonzalez, F.R.; Parizzi, A.; Brcic, R. Evaluating the impact of geodetic corrections on interferometric deformation measurements. In Proceedings of the EUSAR 2018, 12th European Conference on Synthetic Aperture Radar, Aachen, Germany, 4-7 June 2018; pp. 1-5.

35. Shanker, A.P.; Zebker, H. Edgelist phase unwrapping algorithm for time series InSAR analysis. JOSA A 2010, $27,605-612$. [CrossRef]

36. Martín-Martín, A.; Orduna-Malea, E.; Thelwall, M.; López-Cózar, E.D. Google Scholar, Web of Science, and Scopus: A systematic comparison of citations in 252 subject categories. J. Informetr. 2018, 12, 1160-1177. [CrossRef]

37. Halevi, G.; Moed, H.; Bar-Ilan, J. Suitability of Google Scholar as a source of scientific information and as a source of data for scientific evaluation-Review of the literature. J. Informetr. 2017, 11, 823-834. [CrossRef]

38. Bonforte, A.; Ferretti, A.; Prati, C.; Puglisi, G.; Rocca, F. Calibration of atmospheric effects on SAR interferograms by GPS and local atmosphere models: First results. J. Atmos. Sol. Terr. Phys. 2001, 63, 1343-1357. [CrossRef]

39. Carlà, T.; Tofani, V.; Lombardi, L.; Raspini, F.; Bianchini, S.; Bertolo, D.; Thuegaz, P.; Casagli, N. Combination of GNSS, satellite InSAR, and GBInSAR remote sensing monitoring to improve the understanding of a large landslide in high alpine environment. Geomorphology 2019, 335, 62-75. [CrossRef]

40. D'Auria, L.; Pepe, S.; Castaldo, R.; Giudicepietro, F.; Macedonio, G.; Ricciolino, P.; Tizzani, P.; Casu, F.; Lanari, R.; Manzo, M. Magma injection beneath the urban area of Naples: A new mechanism for the 2012-2013 volcanic unrest at Campi Flegrei caldera. Sci. Rep. 2015, 5, 13100. [CrossRef]

41. Da Lio, C.; Teatini, P.; Strozzi, T.; Tosi, L. Understanding land subsidence in salt marshes of the Venice Lagoon from SAR Interferometry and ground-based investigations. Remote Sens. Environ. 2018, 205, 56-70. [CrossRef] 
42. Stramondo, S.; Tesauro, M.; Briole, P.; Sansosti, E.; Salvi, S.; Lanari, R.; Anzidei, M.; Baldi, P.; Fornaro, G.; Avallone, A. The September 26, 1997 Colfiorito, Italy, earthquakes: Modeled coseismic surface displacement from SAR interferometry and GPS. Geophys. Res. Lett. 1999, 26, 883-886. [CrossRef]

43. Teatini, P.; Tosi, L.; Strozzi, T.; Carbognin, L.; Wegmüller, U.; Rizzetto, F. Mapping regional land displacements in the Venice coastland by an integrated monitoring system. Remote Sens. Environ. 2005, 98, 403-413. [CrossRef]

44. Bitelli, G.; Bonsignore, F.; Del Conte, S.; Novali, F.; Pellegrino, I.; Vittuari, L. Integrated use of Advanced InSAR and GPS data for subsidence monitoring. In Engineering Geology for Society and Territory-Volume 5; Springer: Berlin/Heidelberg, Germany, 2015; pp. $147-150$.

45. Tosi, L.; Teatini, P.; Strozzi, T.; Carbognin, L.; Brancolini, G.; Rizzetto, F. Ground surface dynamics in the northern Adriatic coastland over the last two decades. In Rendiconti Lincei; Accademia Nazionale dei Lincei: Roma, Italy, 2010; Volume 21, pp. 115-129.

46. Volpe, M.; Atzori, S.; Piersanti, A.; Melini, D. The 2009 L'Aquila earthquake coseismic rupture: Open issues and new insights from 3D finite element inversion of GPS, InSAR and strong motion data. Ann. Geophys. 2015, 58, 1-17.

47. Bitelli, G.; Bonsignore, F.; Del Conte, S.; Novali, F.; Pellegrino, I.; Vittuari, L. Subsidence monitoring update for Emilia-Romagna region (Italy) by integrated use of InSAR and GNSS data. In Proceedings of the EGU General Assembly Conference Abstracts, Vienna, Austria, 27 April-2 May 2014; p. 15840.

48. Bitelli, G.; Bonsignore, F.; Pellegrino, I.; Vittuari, L. Evolution of the techniques for subsidence monitoring at regional scale: The case of Emilia-Romagna region (Italy). Proc. IAHS 2015, 372, 315-321. [CrossRef]

49. Cenni, N.; Loddo, F.; Zucca, F.; Meisina, C.; Baldi, P.; Belardinelli, M.; Bacchetti, M.; Mantovani, E.; Viti, M.; Casula, G. The spatio-temporal pattern of subsidence in the Po basin monitored by different techniques. Algorithms 2014, 99, $194-214$.

50. Cheloni, D.; De Novellis, V.; Albano, M.; Antonioli, A.; Anzidei, M.; Atzori, S.; Avallone, A.; Bignami, C.; Bonano, M.; Calcaterra, S.J. Geodetic model of the 2016 Central Italy earthquake sequence inferred from InSAR and GPS data. Geophys. Res. Lett. 2017, 44, 6778-6787. [CrossRef]

51. Minet, C.; Goel, K.; Aquino, I.; Avino, R.; Berrino, G.; Caliro, S.; Chiodini, G.; De Martino, P.; Del Gaudio, C.; Ricco, C. Measuring non-linear deformation of the Campi Flegrei caldera (Naples, Italy) using a multi-method insar-geophysical approach. In Proceedings of the 2012 IEEE International Geoscience and Remote Sensing Symposium, Munich, Germany, 22-27 July 2012; pp. 1174-1177.

52. Radicioni, F.; Stoppini, A.; Brigante, R.; Fornaro, G.; Bovenga, F.; NITTI, D.O. Long-term GNSS and SAR data comparison for the deformation monitoring of the Assisi landslide. In Proceedings of the FIG Working Week, Rome, Italy, 6-10 May 2012.

53. Herrera, G.; Notti, D.; García-Davalillo, J.C.; Mora, O.; Cooksley, G.; Sánchez, M.; Arnaud, A.; Crosetto, M. Analysis with C-and X-band satellite SAR data of the Portalet landslide area. Landslides 2011, 8, 195-206. [CrossRef]

54. Fernandez, J.; Prieto, J.F.; Escayo, J.; Camacho, A.G.; Luzón, F.; Tiampo, K.F.; Palano, M.; Abajo, T.; Pérez, E.; Velasco, J. Modeling the two-and three-dimensional displacement field in Lorca, Spain, subsidence and the global implications. Sci. Rep. 2018, 8, 14782 [CrossRef] [PubMed]

55. Fernández, J.; Romero, R.; Carrasco, D.; Luzón, F.; Araña, V. InSAR volcano and seismic monitoring in Spain. Results for the period 1992-2000 and possible interpretations. Opt. Lasers Eng. 2002, 37, 285-297. [CrossRef]

56. De Michele, M.; Briole, P.; Raucoules, D.; Lemoine, A.; Rigo, A. Revisiting the shallow Mw 5.1 Lorca earthquake (southeastern Spain) using C-band InSAR and elastic dislocation modelling. Remote Sens. Lett. 2013, 4, 863-872. [CrossRef]

57. Prieto, J.F.; Gonzalez, P.; Seco, A.; Rodríguez-Velasco, G.; Tunini, L.; Perlock, P.A.; Arjona, A.; Aparicio, A.; Camacho, A.G.; Rundle, J. Geodetic and Structural Research in La Palma, Canary Islands, Spain: 1992-2007 Results. Pure Appl. Geophys. 2009, 166, 1461-1484. [CrossRef]

58. Cong, X.; Eineder, M.; Fritz, T. Atmospheric delay compensation in differential SAR Interferometry for volcanic deformation monitoring-Study case: El Hierro. In Proceedings of the 2012 IEEE International Geoscience and Remote Sensing Symposium, Munich, Germany, 22-27 July 2012; pp. 3887-3890.

59. Samsonov, S.; Tiampo, K.; González, P.J.; Prieto, J.; Camacho, A.G.; Fernández, J. Surface deformation studies of Tenerife Island, Spain from joint GPS-DInSAR observations. In Proceedings of the 2008 Second Workshop on Use of Remote Sensing Techniques for Monitoring Volcanoes and Seismogenic Areas, Naples, Italy, 11-14 November 2008; pp. 1-6.

60. Rodriguez-Lloveras, X.; Puig-Polo, C.; Lantada, N.; Gili, J.A.; Marturià, J. Two decades of GPS/GNSS and DInSAR monitoring of Cardona salt mines (NE of Spain)-natural and mining-induced mechanisms and processes. Proc. IAHS 2020, 382, 167-172. [CrossRef]

61. Alshawaf, F.; Fuhrmann, T.; Heck, B.; Hinz, S.; Knöpfler, A.; Luo, X.; Mayer, M.; Schenk, A.; Thiele, A.; Westerhaus, M. Integration of InSAR and GNSS observations for the determination of atmospheric water vapour. In Earth Observation of Global Changes (EOGC); Springer: Berlin/Heidelberg, Germany, 2013; pp. 147-162.

62. Fuhrmann, T.; Knöpfler, A.; Mayer, M.; Schenk, A.; Westerhaus, M.; Zippelt, K.; Heck, B. An Inventory of Surface Movements in the Upper Rhine Graben Area, Southwest Germany, from SAR-Interferometry, GNSS and Precise Levelling. In IAG 150 Years; Springer: Berlin/Heidelberg, Germany, 2015; pp. 419-425.

63. Heimlich, C.; Masson, F.; Schmittbuhl, J. Geodetic analysis of surface deformation at the power plant of Landau (Germany) related to the 2013-2014 event. In Proceedings of the Proc. European Geothermal Congress, Strasbourg, France, 19-23 September 2016. 
64. Kalia, A.; Frei, M.; Lege, T. A Copernicus downstream-service for the nationwide monitoring of surface displacements in Germany. Remote Sens. Environ. 2017, 202, 234-249. [CrossRef]

65. Heublein, M.; Zhu, X.X.; Alshawaf, F.; Mayer, M.; Bamler, R.; Hinz, S. Compressive sensing for neutrospheric water vapor tomography using GNSS and InSAR observations. In Proceedings of the 2015 IEEE International Geoscience and Remote Sens. Symposium (IGARSS), Milan, Italy, 26-31 July 2015; pp. 5268-5271.

66. Westerhaus, M.; Fuhrmann, T.; Mayer, M.; Zippelt, K.; Heck, B. Resolving the velocity and strain fields in the Upper Rhine Graben Area from a Combination of Levelling, GNSS and InSAR. In Proceedings of the EGU General Assembly Conference Abstracts, Vienna, Austria, 17-22 April 2016; EPSC2016-13011.

67. Oliveira, S.C.; Zêzere, J.L.; Catalão, J.; Nico, G. The contribution of PSInSAR interferometry to landslide hazard in weak rock-dominated areas. Landslides 2015, 12, 703-719. [CrossRef]

68. Marques, F.; Catalão, J.; Hildenbrand, A.; Madureira, P. Ground motion and tectonics in the Terceira Island: Tectonomagmatic interactions in an oceanic rift (Terceira Rift, Azores Triple Junction). Tectonophysics 2015, 651, 19-34. [CrossRef]

69. Fernandes, R.M.; Catalão, J.; Trota, A.N. The contribution of space-geodetic techniques to the understanding of the present-day geodynamics of the Azores triple junction. In Volcanoes of the Azores; Springer: Berlin/Heidelberg, Germany, 2018 ; pp. 57-69.

70. Henriques, M.J.; Lima, J.N.; Falcão, A.P.; Mancuso, M.; Heleno, S.; Falcao, A.P. Land Subsidence in Lisbon Area: Validation Of PsinSAR Results. In Proceedings of the Proc. Of FIG Working Week, Marrakech, Morocco, 18-22 May 2011.

71. Pedersen, R.; Jónsson, S.; Árnadóttir, T.; Sigmundsson, F.; Feigl, K.L. Fault slip distribution of two June 2000 Mw6. 5 earthquakes in South Iceland estimated from joint inversion of InSAR and GPS measurements. Earth Planet. Sci. Lett. 2003, 213, 487-502. [CrossRef]

72. Sigmundsson, F.; Hooper, A.; Hreinsdóttir, S.; Vogfjörd, K.; Ófeigsson, B.; Rafn Heimisson, E.; Dumont, S.; Parks, M.; Spaans, K.; Gudmundsson, G.; et al. Segmented lateral dyke growth in a rifting event at Bárðarbunga volcanic system, Iceland. Nat. Geosci. 2015, 517, 191-195. [CrossRef] [PubMed]

73. Parks, M.; Sigmundsson, F.; Sigurðsson, Ó.; Hooper, A.; Hreinsdóttir, S.; Ófeigsson, B.; Michalczewska, K. Deformation due to geothermal exploitation at Reykjanes, Iceland. J. Volcanol. Geotherm. Res. 2020, 391, 106438. [CrossRef]

74. Spaans, K.; Sigmundsson, F.; Hreinsdóttir, S.; Öfeigsson, B. High resolution surface deformation measurements in Iceland's Northern Volcanic Zone: Unraveling multiple deformation sources using InSAR and GPS. In Proceedings of the EGU General Assembly Conference Abstracts, Vienna, Austria, 22-27 April 2012; p. 10604.

75. Eriksen, H.Ø.; Lauknes, T.R.; Larsen, Y.; Corner, G.D.; Bergh, S.G.; Dehls, J.; Kierulf, H.P. Visualizing and interpreting surface displacement patterns on unstable slopes using multi-geometry satellite SAR interferometry (2D InSAR). Remote Sens. Environ. 2017, 191, 297-312. [CrossRef]

76. L'Heureux, J.; Long, M.; Vanneste, M.; Sauvin, G.; Hansen, L.; Polom, U.; Lecomte, I.; Dehls, J.; Janbu, N. On the prediction of settlement from high-resolution shear-wave reflection seismic data: The Trondheim harbour case study, mid Norway. Eng. Geol. 2013, 167, 72-83. [CrossRef]

77. Shamshiri, R.; Motagh, M.; Nahavandchi, H.; Haghighi, M.H.; Hoseini, M.J.R.S.o.E. Improving tropospheric corrections on large-scale Sentinel-1 interferograms using a machine learning approach for integration with GNSS-derived zenith total delay (ZTD). Remote Sens. Environ. 2020, 239, 111608. [CrossRef]

78. Böhme, M.; Bunkholt, H.; Oppikofer, T.; Dehls, J.; Hermanns, R.; Eriksen, H.; Lauknes, T.; Eiken, T. Using 2D InSAR, dGNSS and structural field data to understand the deformation mechanism of the unstable rock slope Gamanjunni 3, northern Norway. Landslides and Engineered Slopes. Experience, Theory and Practice. In Proceedings of the 12th International Symposium on Landslides, Napoli, Italy, 12-19 June 2016; p. 443.

79. Dehls, J.; Fischer, L.; Böhme, M.; Saintot, A.; Hermanns, R.; Oppikofer, T.; Lauknes, T.; Larsen, Y.; Blikra, L. Landslide Monitoring in Western Norway Using High Resolution TerraSAR-X and Radarsat-2 InSAR; CRC Press: Milton, UK, 2012; pp. $1321-1325$.

80. Dehls, J.; Henderson, I.; Lauknes, T.; Larsen, Y. Regional landslide mapping and detailed site characterization using InSAR. In Proceedings of the "GeoEdmonton", Edmonton, AB, Canada, 21-24 September 2008; pp. 21-24.

81. Avallone, A.; Cirella, A.; Cheloni, D.; Tolomei, C.; Theodoulidis, N.; Piatanesi, A.; Briole, P.; Ganas, A. Near-source high-rate GPS, strong motion and InSAR observations to image the 2015 Lefkada (Greece) Earthquake rupture history. Sci. Rep. 2017, 7, 10358. [CrossRef]

82. Lagios, E.; Papadimitriou, P.; Novali, F.; Sakkas, V.; Fumagalli, A.; Vlachou, K.; Del Conte, S. Combined seismicity pattern analysis, DGPS and PSInSAR studies in the broader area of Cephalonia (Greece). Tectonophysics 2012, 524, 43-58. [CrossRef]

83. Papoutsis, I.; Papanikolaou, X.; Floyd, M.; Ji, K.; Kontoes, C.; Paradissis, D.; Zacharis, V. Mapping inflation at Santorini volcano, Greece, using GPS and InSAR. Geophys. Res. Lett. 2013, 40, 267-272. [CrossRef]

84. Elias, P.; Sykioti, O.; Drakatos, G.; Paronis, D.; Chousianitis, K.; Sabatakakis, N.; Anastasopoulos, V.; Briole, P. Landslides modelling and monitoring by exploiting satellite SAR acquisitions, optical imagery, GPS and in-situ measurements in Greece. Preliminary results. In Proceedings of the EGU General Assembly Conference Abstracts, Vienna, Austria, 27 April-2 May $2014 ;$ p. 4402.

85. Briole, P.; Avallone, A.; Agatza-Balodimou, E.; Billiris, H.; Charade, O.; Lyon-Caen, H.; Mitsakaki, C.; Papazissi, K.; Paradissis, D.; Veis, G. A ten years analysis of deformation in the Corinthian Gulf via GPS and SAR Interferometry. In Proceedings of the Wegener Meeting, Athens, Greece, 12-14 June 2002. 
86. Sakkas, V.; Novali, F.; Lagios, E.; Ferretti, A.; Vassilopoulou, S.; Bellotti, F.; Allievi, J. Combined Squee-SAR TM and GPS ground deformation study of Nisyros-Yali volcanic field (Greece) for period 2002-2012. In Proceedings of the 2015 IEEE International Geoscience and Remote Sensing Symposium (IGARSS), Milan, Italy, 26-31 July 2015; pp. 4672-4675.

87. Borgia, A.; Lanari, R.; Sansosti, E.; Tesauro, M.; Berardino, P.; Fornaro, G.; Neri, M.; Murray, J. Actively growing anticlines beneath Catania from the distal motion of Mount Etna's decollement measured by SAR interferometry and GPS. Geophys. Res. Lett. 2000, 27, 3409-3412. [CrossRef]

88. Salvi, S.; Stramondo, S.; Cocco, M.; Tesauro, M.; Hunstad, I.; Anzidei, M.; Briole, P.; Baldi, P.; Sansosti, E.; Fornaro, G. Modeling coseismic displacements resulting from SAR interferometry and GPS measurements during the 1997 Umbria-Marche seismic sequence. J. Seismol. 2000, 4, 479-499. [CrossRef]

89. Colesanti, C.; Wasowski, J. Investigating landslides with space-borne Synthetic Aperture Radar (SAR) interferometry. Eng. Geol. 2006, 88, 173-199. [CrossRef]

90. Novellino, A.; Cigna, F.; Brahmi, M.; Sowter, A.; Bateson, L.; Marsh, S. Assessing the Feasibility of a National InSAR Ground Deformation Map of Great Britain with Sentinel-1. Geosciences 2017, 7, 19. [CrossRef]

91. Lanari, R.; Bonano, M.; Casu, F.; Luca, C.D.; Manunta, M.; Manzo, M.; Onorato, G.; Zinno, I. Automatic generation of sentinel-1 continental scale DInSAR deformation time series through an extended P-SBAS processing pipeline in a cloud computing environment. Remote Sens. 2020, 12, 2961. [CrossRef]

92. Fuhrmann, T.; Caro Cuenca, M.; Knöpfler, A.; Van Leijen, F.; Mayer, M.; Westerhaus, M.; Hanssen, R.; Heck, B. Estimation of small surface displacements in the Upper Rhine Graben area from a combined analysis of PS-InSAR, levelling and GNSS data. Geophys. J. Int. 2015, 203, 614-631. [CrossRef]

93. Fuhrmann, T.; Knöpfler, A.; Mayer, M.; Schenk, A.; Westerhaus, M.; Zippelt, K.; Heck, B. Towards a fusion of SAR-interferometry, GNSS and precise levelling in the Upper Rhine Graben Area, Southwest Germany. In Proceedings of the ESA Living Planet Symposium, Edinburgh, UK, 9-13 September 2013. SP-722.

94. Haghshenas Haghighi, M.; Motagh, M. Sentinel-1 InSAR over Germany: Large-scale interferometry, atmospheric effects, and ground deformation mapping. Zeitschrift Geodäsie Geoinformation Landmanagement 2017, 2017, 245-256.

95. Fiaschi, S.; Fabris, M.; Floris, M.; Achilli, V. Estimation of land subsidence in deltaic areas through differential SAR interferometry: The Po River Delta case study (Northeast Italy). Int. J. Remote Sens. 2018, 39, 8724-8745. [CrossRef]

96. Zerbini, S.; Richter, B.; Rocca, F.; van Dam, T.; Matonti, F. A combination of space and terrestrial geodetic techniques to monitor land subsidence: Case study, the Southeastern Po Plain, Italy. J. Geophys. Res. Solid Earth 2007, 112, B05401. [CrossRef]

97. Bock, Y.; Wdowinski, S.; Ferretti, A.; Novali, F.; Fumagalli, A. Recent subsidence of the Venice Lagoon from continuous GPS and interferometric synthetic aperture radar. Geochem. Geophys. Geosyst. 2012, 13. [CrossRef]

98. Teatini, P.; Tosi, L.; Strozzi, T.; Carbognin, L.; Cecconi, G.; Rosselli, R.; Libardo, S. Resolving land subsidence within the Venice Lagoon by persistent scatterer SAR interferometry. Phys. Chem. Earth Parts A/B/C 2012, 40, 72-79. [CrossRef]

99. Da Lio, C.; Tosi, L. Land subsidence in the Friuli Venezia Giulia coastal plain, Italy: 1992-2010 results from SAR-based interferometry. Sci. Total Environ. 2018, 633, 752-764. [CrossRef]

100. Del Soldato, M.; Farolfi, G.; Rosi, A.; Raspini, F.; Casagli, N. Subsidence Evolution of the Firenze-Prato-Pistoia Plain (Central Italy) Combining PSI and GNSS Data. Remote Sens. 2018, 10, 1146. [CrossRef]

101. Cianflone, G.; Tolomei, C.; Brunori, C.A.; Dominici, R. InSAR time series analysis of natural and anthropogenic coastal plain subsidence: The case of Sibari (Southern Italy). Remote Sens. 2015, 7, 16004-16023. [CrossRef]

102. Béjar-Pizarro, M.; Guardiola-Albert, C.; García-Cárdenas, R.P.; Herrera, G.; Barra, A.; López Molina, A.; Tessitore, S.; Staller, A.; Ortega-Becerril, J.A.; García-García, R.P. Interpolation of GPS and geological data using InSAR deformation maps: Method and application to land subsidence in the alto guadalentín aquifer (SE Spain). Remote Sens. 2016, 8, 965. [CrossRef]

103. Bonì, R.; Herrera, G.; Meisina, C.; Notti, D.; Béjar-Pizarro, M.; Zucca, F.; González, P.J.; Palano, M.; Tomás, R.; Fernández, J. Twenty-year advanced DInSAR analysis of severe land subsidence: The Alto Guadalentín Basin (Spain) case study. Eng. Geol. 2015, 198, 40-52. [CrossRef]

104. Heleno, S.I.; Oliveira, L.G.; Henriques, M.J.; Falcão, A.P.; Lima, J.N.; Cooksley, G.; Ferretti, A.; Fonseca, A.M.; Lobo-Ferreira, J.P.; Fonseca, J.F. Persistent scatterers interferometry detects and measures ground subsidence in Lisbon. Remote Sens. Environ. 2011, 115, 2152-2167. [CrossRef]

105. Graniczny, M.; Cyziene, J.; van Leijen, F.; Minkevicius, W.; Mikulenas, V.; Satkunas, J.; Przylucka, M.; Kowalski, Z.; Uscinowicz, S.; Jeglinski, W. Vertical ground movements in the Polish and Lithuanian Baltic coastal area as measured by satellite interferometry. Baltica 2015, 28. [CrossRef]

106. Krynski, J.; Zak, L.; Ziolkowski, D.; Cisak, J.; Lagiewska, M. Estimation of height changes of GNSS stations from the solutions of short vectors and PSI measurements. Geod. Cartogr. 2017, 66, 73-83. [CrossRef]

107. Armaş, I.; Gheorghe, M.; Lendvai, A.M.; Dumitru, P.D.; Bădescu, O.; Călin, A. InSAR validation based on GNSS measurements in Bucharest. Int. J. Remote Sens. 2016, 37, 5565-5580. [CrossRef]

108. Armaş, I.; Mendes, D.A.; Popa, R.-G.; Gheorghe, M.; Popovici, D. Long-term ground deformation patterns of Bucharest using multi-temporal InSAR and multivariate dynamic analyses: A possible transpressional system? Sci. Rep. 2017, 7, 43762. [CrossRef]

109. Czikhardt, R.; Papčo, J.; Bakoň, M. Feasibility of the Sentinel-1 Multi-temporal InSAR system based on the SNAP and StaMPS: Case study from the Tatra Mts., Slovakia. Procedia Comput. Sci. 2018, 138, 366-373. [CrossRef] 
110. Tondaś, D.; Pawłuszek, K.; Ilieva, M.; Kapłon, J.; Rohm, W. Investigation for mining-induced deformation in Upper Silesia Coal Basin with multi-GNSS in Near Real-Time. In Proceedings of the 4th Joint International Symposium on Deformation Monitoring (JISDM), Athens, Greece, 15-17 May 2019.

111. Kadlečík, P.; Kajzar, V.; Nekvasilová, Z.; Wegmüller, U.; Doležalová, H. Evaluation of the subsidence based on dInSAR and GPS measurements near Karvina, Czech Republic. AUC Geogr. 2015, 50, 51-61. [CrossRef]

112. Alshammari, L.; Large, D.J.; Boyd, D.S.; Sowter, A.; Anderson, R.; Andersen, R.; Marsh, S. Long-term peatland condition assessment via surface motion monitoring using the ISBAS DInSAR technique over the Flow Country, Scotland. Remote Sens. 2018, 10, 1103. [CrossRef]

113. Mason, P.; Ghail, R.; Bischoff, C.; Skipper, J. Detecting and Monitoring Small-Scale Discrete Ground Movements across London, Using Persistent Scatterer InSAR (PSI). 2015. Available online: https://spiral.imperial.ac.uk/handle/10044/1/26693 (accessed on 31 March 2021).

114. Bardi, F.; Raspini, F.; Ciampalini, A.; Kristensen, L.; Rouyet, L.; Lauknes, T.R.; Frauenfelder, R.; Casagli, N. Space-borne and ground-based InSAR data integration: The Åknes test site. Remote Sens. 2016, 8, 237. [CrossRef]

115. Booth, A.M.; Dehls, J.; Eiken, T.; Fischer, L.; Hermanns, R.L.; Oppikofer, T. Integrating diverse geologic and geodetic observations to determine failure mechanisms and deformation rates across a large bedrock landslide complex: The Osmundneset landslide, Sogn og Fjordane, Norway. Landslides 2015, 12, 745-756. [CrossRef]

116. Eckerstorfer, M.; Eriksen, H.Ø.; Rouyet, L.; Christiansen, H.H.; Lauknes, T.R.; Blikra, L.H. Comparison of geomorphological field mapping and 2D-InSAR mapping of periglacial landscape activity at Nordnesfjellet, northern Norway. Earth Surface Process. Landf. 2018, 43, 2147-2156. [CrossRef]

117. Delaloye, R.; Strozzi, T.; Lambiel, C.; Perruchoud, E. Landslide-like development of rockglaciers detected with ERS-1/2 SAR interferometry. In Proceedings of the ESA FRINGE Symposium 2007, Frascati, Italy, 26-30 November 2007.

118. Kenner, R.; Phillips, M.; Beutel, J.; Limpach, P.; Papke, J.; Hasler, A.; Raetzo, H. Investigating the dynamics of a rock glacier using terrestrial laser scanning, time-lapse photography, in situ GPS measurements and satellite SAR inter-ferometry: Ritigraben rock glacier, Switzerland. In Proceedings of the International Conference on Permafrost, Potsdam, Germany, 20-24 June 2016; pp. 20-24.

119. Barboux, C.; Delaloye, R.; Strozzi, T.; Collet, C.; Raetzo, H. TSX InSAR assessment for slope instabilities monitoring in alpine periglacial environment (Western Swiss Alps, Switzerland). In Proceedings of the Proc. ESA FRINGE, Frascati, Italy, 19-23 September 2011; pp. 19-23.

120. Barboux, C.; Strozzi, T.; Delaloye, R.; Wegmüller, U.; Collet, C. Mapping slope movements in Alpine environments using TerraSAR-X interferometric methods. ISPRS J. Photogramm. Remote Sens. 2015, 109, 178-192. [CrossRef]

121. Strozzi, T.; Ambrosi, C.; Raetzo, H. Interpretation of aerial photographs and satellite SAR interferometry for the inventory of landslides. Remote Sens. 2013, 5, 2554-2570. [CrossRef]

122. Strozzi, T.; Delaloye, R.; Kääb, A.; Ambrosi, C.; Perruchoud, E.; Wegmüller, U. Combined observations of rock mass movements using satellite SAR interferometry, differential GPS, airborne digital photogrammetry, and airborne photography interpretation. J. Geophys. Res. Earth Surf. 2010, 115. [CrossRef]

123. Bayer, B.; Simoni, A.; Schmidt, D.; Bertello, L. Using advanced InSAR techniques to monitor landslide deformations induced by tunneling in the Northern Apennines, Italy. Eng. Geol. 2017, 226, 20-32. [CrossRef]

124. Lu, P.; Catani, F.; Tofani, V.; Casagli, N. Quantitative hazard and risk assessment for slow-moving landslides from Persistent Scatterer Interferometry. Landslides 2014, 11, 685-696. [CrossRef]

125. Crosetto, M.; Gili, J.; Monserrat, O.; Cuevas-González, M.; Corominas, J.; Serral, D. Interferometric SAR monitoring of the Vallcebre landslide (Spain) using corner reflectors. Nat. Hazards Earth Syst. Sci. 2013, 13, 923-933. [CrossRef]

126. García-Davalillo, J.C.; Herrera, G.; Notti, D.; Strozzi, T.; Álvarez-Fernández, I. DInSAR analysis of ALOS PALSAR images for the assessment of very slow landslides: The Tena Valley case study. Landslides 2014, 11, 225-246. [CrossRef]

127. Herrera, G.; Gutiérrez, F.; García-Davalillo, J.; Guerrero, J.; Notti, D.; Galve, J.; Fernández-Merodo, J.; Cooksley, G. Multi-sensor advanced DInSAR monitoring of very slow landslides: The Tena Valley case study (Central Spanish Pyrenees). Remote Sens. Environ. 2013, 128, 31-43. [CrossRef]

128. Komac, M.; Holley, R.; Mahapatra, P.; van der Marel, H.; Bavec, M. Coupling of GPS/GNSS and radar interferometric data for a 3D surface displacement monitoring of landslides. Landslides 2015, 12, 241-257. [CrossRef]

129. Mahapatra, P.; van der Marel, H.; Hanssen, R.; Holley, R.; Samiei-Esfahany, S.; Komac, M.; Fromberg, A. Radar transponders and their combination with GNSS for deformation monitoring. In Proceedings of the 2012 the IEEE International Geoscience and Remote Sensing Symposium, Munich, Germany, 22-27 July 2012; pp. 3891-3894.

130. Mahapatra, P.S.; Samiei-Esfahany, S.; van der Marel, H.; Hanssen, R.F. On the use of transponders as coherent radar targets for SAR interferometry. IEEE Trans. Geosci. Remote Sens. 2013, 52, 1869-1878. [CrossRef]

131. Mantovani, M.; Devoto, S.; Piacentini, D.; Prampolini, M.; Soldati, M.; Pasuto, A. Advanced SAR interferometric analysis to support geomorphological interpretation of slow-moving coastal landslides (Malta, Mediterranean Sea). Remote Sens. 2016, 8, 443. [CrossRef]

132. Piacentini, D.; Devoto, S.; Mantovani, M.; Pasuto, A.; Prampolini, M.; Soldati, M. Landslide susceptibility modeling assisted by Persistent Scatterers Interferometry (PSI): An example from the northwestern coast of Malta. Nat. Hazards 2015, 78, 681-697. [CrossRef] 
133. Atanasova, M.; Nikolov, H. Ground displacements detection in Trifon Zarezan landslide based on GNSS and SAR data. MMM Geo Inf. 2018, 11, 7-15.

134. Themistocleous, K.; Danezis, C.; Gikas, V. Monitoring ground deformation of cultural heritage sites using SAR and geodetic techniques: The case study of Choirokoitia, Cyprus. Appl. Geomat. 2020, 1-13. [CrossRef]

135. Raucoules, D.; De Michele, M.; Malet, J.-P.; Ulrich, P. Time-variable 3D ground displacements from high-resolution synthetic aperture radar (SAR). Application to La Valette landslide (South French Alps). Remote Sens. Environ. 2013, 139, 198-204. [CrossRef]

136. Bozsó, I.; Bányai, L.; Hooper, A.; Sz, E.; Wesztergom, V. Integration of Sentinel-1 Interferometry and GNSS Networks for Derivation of 3-D Surface Changes. IEEE Geosci. Remote Sens. Lett. 2021, 18, 692-696. [CrossRef]

137. Cheloni, D.; Giuliani, R.; D'Anastasio, E.; Atzori, S.; Walters, R.; Bonci, L.; D'Agostino, N.; Mattone, M.; Calcaterra, S.; Gambino, P. Coseismic and post-seismic slip of the 2009 L'Aquila (central Italy) Mw 6.3 earthquake and implications for seismic potential along the Campotosto fault from joint inversion of high-precision levelling, InSAR and GPS data. Tectonophysics 2014, 622, 168-185. [CrossRef]

138. Wang, Y.-Z.; Zhu, J.-J.; Ou, Z.-Q.; Li, Z.-W.; Xing, X.-M. Coseismic slip distribution of 2009 L'Aquila earthquake derived from InSAR and GPS data. J. Cent. South Univ. 2012, 19, 244-251. [CrossRef]

139. Nespoli, M.; Belardinelli, M.E.; Gualandi, A.; Serpelloni, E.; Bonafede, M. Poroelasticity and fluid flow modeling for the 2012 Emilia-Romagna earthquakes: Hints from GPS and InSAR data. Geofluids 2018, 1-15. [CrossRef]

140. Cheloni, D. Geodetic model of the 2016 Central Italy earthquake sequence inferred from InSAR and GPS measurements. In Proceedings of the EGU General Assembly Conference Abstracts, Vienna, Austria, 23-28 April 2017; p. 9191.

141. Cheloni, D.; D’Agostino, N.; Scognamiglio, L.; Tinti, E.; Bignami, C.; Avallone, A.; Giuliani, R.; Calcaterra, S.; Gambino, P.; Mattone, M. Heterogeneous Behavior of the Campotosto Normal Fault (Central Italy) Imaged by InSAR GPS and Strong-Motion Data: Insights from the 18 January 2017 Events. Remote Sens. 2019, 11, 1482. [CrossRef]

142. Wang, L.; Gao, H.; Feng, G.; Xu, W. Source parameters and triggering links of the earthquake sequence in central Italy from 2009 to 2016 analyzed with GPS and InSAR data. Tectonophysics 2018, 744, 285-295. [CrossRef]

143. Walters, R.J.; Gregory, L.C.; Wedmore, L.N.; Craig, T.J.; McCaffrey, K.; Wilkinson, M.; Chen, J.; Li, Z.; Elliott, J.R.; Goodall, H. Dual control of fault intersections on stop-start rupture in the 2016 Central Italy seismic sequence. Earth Planet. Sci. Lett. 2018, 500, 1-14. [CrossRef]

144. Farolfi, G.; Bianchini, S.; Casagli, N. Integration of GNSS and satellite InSAR data: Derivation of fine-scale vertical surface motion maps of Po Plain, Northern Apennines, and Southern Alps, Italy. IEEE Trans. Geosci. Remote Sens. 2018, 57, 319-328. [CrossRef]

145. Vollrath, A.; Zucca, F.; Bekaert, D.; Bonforte, A.; Guglielmino, F.; Hooper, A.J.; Stramondo, S. Decomposing DInSAR time-series into 3-D in combination with GPS in the case of low strain rates: An application to the Hyblean Plateau, Sicily, Italy. Remote Sens. 2017, 9, 33. [CrossRef]

146. Sakkas, V.; Novali, F.; Vassilopoulou, S.; Damiata, B.N.; Fumagalli, A.; Lagios, E. Combined PSI And Differential GPS Study Of Zakynthos Island (W. Greece) For The Period 1992-2012. In Proceedings of the ESA Living Planet Symposium, Edinburgh, UK, 9-13 September 2013; p. 214.

147. Briole, P.; Elias, P.; Parcharidis, I.; Bignami, C.; Benekos, G.; Samsonov, S.; Kyriakopoulos, C.; Stramondo, S.; Chamot-Rooke, N.; Drakatou, M. The seismic sequence of January-February 2014 at Cephalonia Island (Greece): Constraints from SAR interferometry and GPS. Geophys. Suppl. Mon. Not. R. Astron. Soc. 2015, 203, 1528-1540. [CrossRef]

148. Decriem, J.; Árnadóttir, T.J.T. Transient crustal deformation in the South Iceland Seismic Zone observed by GPS and InSAR during 2000-2008. Tectonophysics 2012, 581, 6-18. [CrossRef]

149. Metzger, S.; Jónsson, S. Plate boundary deformation in North Iceland during 1992-2009 revealed by InSAR time-series analysis and GPS. Tectonophysics 2014, 634, 127-138. [CrossRef]

150. Juncu, D.; Árnadóttir, T.; Hooper, A.; Gunnarsson, G. Anthropogenic and natural ground deformation in the Hengill geothermal area, Iceland. J. Geophys. Res. Solid Earth 2017, 122, 692-709. [CrossRef]

151. Jonsson, S. Importance of post-seismic viscous relaxation in southern Iceland. Nat. Geosci. 2008, 1, 136-139. [CrossRef]

152. Szúcs, E.; Bozsó, I.; Kovács, I.J.; Bányai, L.; Gál, Á.; Szakács, A.; Wesztergom, V. Probing tectonic processes with space geodesy in the south Carpathians: Insights from archive SAR data. Acta Geod. Geophys. 2018, 53, 331-345. [CrossRef]

153. Gheorghe, M.; Armaș, I.; Năstase, E.-I.; Munteanu, A. Potential of InSAR Monitoring for Seismic Areas in Romanian; Center for Risk Studies, Spatial Modelling, Terrestrial and Coastal System Dynamics: Bucharest, Romania, 2018; pp. $23-31$.

154. Zoran, M. Use of geospatial and in situ information for seismic hazard assessment in Vrancea area, Romania. In Proceedings of the 2008 Second Workshop on Use of Remote Sensing Techniques for Monitoring Volcanoes and Seismogenic Areas, Naples, Italy, 11-14 November 2008; pp. 1-5.

155. Ganas, A.; Elias, P.; Briole, P.; Cannavo, F.; Valkaniotis, S.; Tsironi, V.; Partheniou, E. Ground deformation and seismic fault model of the M6. 4 Durres (Albania) Nov. 26, 2019 earthquake, based on GNSS/INSAR observations. Geosciences 2020, 10, 210. [CrossRef]

156. Grassi, F.; Cenni, N.; Mancini, F. Combination of satellite SAR and GNSS data of co-seismic deformation after the November 26, 2019 Albania earthquake: First results. In Proceedings of the EGU General Assembly Conference Abstracts, Vienna, Austria, 4-8 May 2020; p. 4553. 
157. Atanasova, M.; Nikolov, H. Detection of the Earth crust deformation in Provadia area using InSAR technique. In XXVI International Symposium on Modern Technologies, Education and Professional Practice in Geodesy and Related Fields; Sofia, Bulgary, 2016. Available online: https://www.researchgate.net/publication/334964442_XXIV_-th_INTERNATIONAL_SYMPOSIUM_ MODERN_TECHNOLOGIES_EDUCATION_AND_PROFESSIONAL_PRACTICE_IN_GEODESY_AND_RELATED_FIELDS_ Study_of_the_earth_crust_movements_on_the_territory_of_Bulgaria_with_GPS (accessed on 31 March 2021).

158. Lagios, E.; Sakkas, V.; Novali, F.; Bellotti, F.; Ferretti, A.; Vlachou, K.; Dietrich, V. SqueeSAR ${ }^{\mathrm{TM}}$ and GPS ground deformation monitoring of Santorini Volcano (1992-2012): Tectonic implications. Tectonophysics 2013, 594, 38-59. [CrossRef]

159. Lagios, E.; Sakkas, V.; Novali, F.; Ferreti, A.; Damiata, B.; Dietrich, V.J. Reviewing and updating (1996-2012) ground deformation in Nisyros Volcano (Greece) determined by GPS and SAR Interferometric Techniques (1996-2012). In Nisyros Volcano; Springer: Berlin/Heidelberg, Germany, 2018; pp. 285-301.

160. Currenti, G.; Napoli, R.; Del Negro, C. Toward a realistic deformation model of the 2008 magmatic intrusion at Etna from combined DInSAR and GPS observations. Earth Planet. Sci. Lett. 2011, 312, 22-27. [CrossRef]

161. Palano, M.; Puglisi, G.; Gresta, S. Ground deformation patterns at Mt. Etna from 1993 to 2000 from joint use of InSAR and GPS techniques. J. Volcanol. Geotherm. Res. 2008, 169, 99-120. [CrossRef]

162. Fernández, J.; González-Matesanz, F.; Prieto, J.; Rodríguez-Velasco, G.; Staller, A.; Alonso-Medina, A.; Charco, M. GPS monitoring in the NW part of the volcanic island of Tenerife, Canaries, Spain: Strategy and results. Pure Appl. Geophys. 2004, 161, 1359-1377. [CrossRef]

163. Fernández, J.; Tizzani, P.; Manzo, M.; Borgia, A.; González, P.; Martí, J.; Pepe, A.; Camacho, A.; Casu, F.; Berardino, P. Gravitydriven deformation of Tenerife measured by InSAR time series analysis. Geophys. Res. Lett. 2009, 36. [CrossRef]

164. Alshawaf, F.; Fersch, B.; Hinz, S.; Kunstmann, H.; Mayer, M.; Meyer, F. Water vapor mapping by fusing InSAR and GNSS remote sensing data and atmospheric simulations. Hydrology Earth Syst. Sci. 2015, 19, 4747-4764. [CrossRef]

165. Alshawaf, F.; Fuhrmann, T.; Heck, B.; Hinz, S.; Knoepfler, A.; Luo, X.; Mayer, M.; Schenk, A.; Thiele, A.; Westerhaus, M. Atmospheric water vapour determination by the integration of INSAR and GNSS observations. In Proceedings of the Fringe 2011 Workshop, Frascati, Italy, 9-23 September 2011. ESA SP-697.

166. Alshawaf, F.; Hinz, S.; Mayer, M.; Meyer, F.J. Constructing accurate maps of atmospheric water vapor by combining interferometric synthetic aperture radar and GNSS observations. J. Geophys. Res. Atmos. 2015, 120, 1391-1403. [CrossRef]

167. Benevides, P.; Nico, G.; Catalao, J.; Miranda, P. Merging SAR interferometry and GPS tomography for high-resolution mapping of 3D tropospheric water vapour. In Proceedings of the 2015 IEEE International Geoscience and Remote Sensing Symposium (IGARSS), Milan, Italy, 26-31 July 2015; pp. 3607-3610.

168. Benevides, P.; Nico, G.; Catalão, J.; Miranda, P.M. Bridging InSAR and GPS tomography: A new differential geometrical constraint. IEEE Trans. Geosci. Remote Sens. 2015, 54, 697-702. [CrossRef]

169. Mateus, P.; Catalão, J.; Nico, G. Sentinel-1 interferometric SAR mapping of precipitable water vapor over a country-spanning area. IEEE Trans. Geosci. Remote Sens. 2017, 55, 2993-2999. [CrossRef]

170. Cheng, S.; Perissin, D.; Chen, F.; Lin, H. Atmospheric delay analysis from GPS and InSAR. In Proceedings of the 2011 IEEE International Geoscience and Remote Sensing Symposium, Vancouver, BC, Canada, 24-29 July 2011; pp. 1650-1653.

171. Chen, G.; Hay, G.J.; Carvalho, L.M.; Wulder, M.A. Object-based change detection. Int. J. Remote Sens. 2012, $33,4434-4457$. [CrossRef]

172. Heublein, M.; Alshawaf, F.; Erdnüß, B.; Zhu, X.X.; Hinz, S. Compressive sensing reconstruction of 3D wet refractivity based on GNSS and InSAR observations. J. Geod. 2019, 93, 197-217. [CrossRef]

173. Milczarek, W.; Kopeć, A.; Głąbicki, D. Estimation of tropospheric and ionospheric delay in DInSAR calculations: Case study of areas showing (natural and induced) seismic activity. Remote Sens. 2019, 11, 621. [CrossRef]

174. Roque, D.; Simonetto, E.; Falcão, A.; Perissin, D.; Durand, F.; Morel, L.; Fonseca, A.; Polidori, L. An analysis of displacement measurements for Lisbon, Portugal, using combined InSAR and GNSS data. Orbit 2008, 34209, 28.

175. Wilgan, K.; Geiger, A. High-resolution models of tropospheric delays and refractivity based on GNSS and numerical weather prediction data for alpine regions in Switzerland. J. Geod. 2019, 93, 819-835. [CrossRef]

176. Cuenca, M.C.; Hanssen, R.; Hooper, A.; Arikan, M. Surface deformation of the whole Netherlands after PSI analysis. In Proceedings of the Fringe 2011 Workshop, Frascati, Italy, 9-23 September 2011; pp. 19-23.

177. Gee, D.; Sowter, A.; Grebby, S.; de Lange, G.; Athab, A.; Marsh, S. National geohazards mapping in Europe: Interferometric analysis of the Netherlands. Eng. Geol. 2019, 256, 1-22. [CrossRef]

178. Hanssen, R.; Caro Cuenca, M.; Klees, R.; Van der Marel, H. Decadal vertical deformation of the Netherlands via the geodetic integration of gravimetry, GNSS, leveling and SAR interferometry. In Proceedings of the AGU Fall Meeting Abstracts, San Francisco, CA, USA, 3-7 December 2012.

179. Parizzi, A.; Rodriguez Gonzalez, F.; Brcic, R. A covariance-based approach to merging InSAR and GNSS displacement rate measurements. Remote Sens. 2020, 12, 300. [CrossRef]

180. Hanssen, R.F.; Van Leijen, F.J. Monitoring deformation of water defense structures using satellite radar interferometry. In Proceedings of the 13th FIG Symposium on Deformation Measurement and Analysis, Lisbon, Portugal, 12-15 May 2008.

181. Hanssen, R.F.; van Leijen, F.J. Monitoring water defense structures using radar interferometry. In Proceedings of the 2008 the IEEE Radar Conference, Rome, Italy, 26-30 May 2008; pp. 1-4. 
182. Bonì, R.; Bosino, A.; Meisina, C.; Novellino, A.; Bateson, L.; McCormack, H. A methodology to detect and characterize uplift phenomena in urban areas using Sentinel-1 data. Remote Sens. 2018, 10, 607. [CrossRef]

183. Gheorghe, M.; Armaș, I.; Dumitru, P.; Călin, A.; Bădescu, O.; Necsoiu, M. Monitoring subway construction using Sentinel-1 data: A case study in Bucharest, Romania. Int. J. Remote Sens. 2020, 41, 2644-2663. [CrossRef]

184. Bignami, C.; Stramondo, S. Ground deformation observed at Kozloduy (Bulgaria) and Akkuyu (Turkey) NPPS by means of

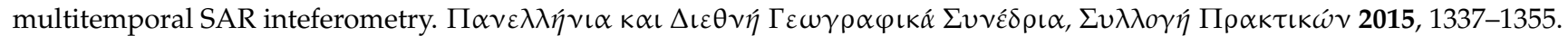

185. Ponton, F.; Walpersdorf, A.; Gay, M.; Trouvé, E.; Mugnier, J.-L.; Fallourd, R.; Cotte, N.; Ott, L.; Serafini, J. GPS and TerraSAR-X time series measure temperate glacier flow in the Mont Blanc massif (France): The Argentière glacier test site. In Proceedings of the EGU General Assembly Conference Abstracts, Vienna, Austria, 2-27 April 2012; p. 9525.

186. Stockamp, J.; Li, Z.; Bishop, P.; Hansom, J.; Rennie, A.; Petrie, E.; Tanaka, A.; Bingley, R.; Hansen, D.; Ouwehand, L. Investigating glacial isostatic adjustment in Scotland with InSAR and GPS observations. In Proceedings of the FRINGE, Frascati, Italy, 23-27 March 2015; pp. 23-27.

187. Poitevin, C.; Wöppelmann, G.; Raucoules, D.; Le Cozannet, G.; Marcos, M.; Testut, L. Vertical land motion and relative sea level changes along the coastline of Brest (France) from combined space-borne geodetic methods. Remote Sens. Environ. 2019, 222, 275-285. [CrossRef]

188. Riedel, A.; Riedel, B.; Tengen, D.; Gerke, M. Investigations on vertical land movements along the North Sea and Baltic Sea coast in Germany with PS Interferometry. Int. Arch. Photogramm. Remote Sens. Spat. Inf. Sci. 2019, 42. [CrossRef]

189. Zerbini, S.; Raicich, F.; Prati, C.M.; Bruni, S.; Del Conte, S.; Errico, M.; Santi, E. Sea-level change in the Northern Mediterranean Sea from long-period tide gauge time series. Earth Sci. Rev. 2017, 167, 72-87. [CrossRef]

190. Wilson, M.; Atkinson, P. The use of elevation data in flood inundation modelling: A comparison of ERS interferometric SAR and combined contour and differential GPS data. Int. J. River Basin Manag. 2005, 3, 3-20. [CrossRef]

191. Ilieva, M.; Rudziński, Ł.; Pawłuszek-Filipiak, K.; Lizurek, G.; Kudłacik, I.; Tondaś, D.; Olszewska, D. Combined Study of a Significant Mine Collapse Based on Seismological and Geodetic Data-29 January 2019, Rudna Mine, Poland. Remote Sens. 2020, 12, 1570. [CrossRef]

192. Van Der Wal, D.; Herman, P.M.; Wielemaker-van Den Dool, A. Characterisation of surface roughness and sediment texture of intertidal flats using ERS SAR imagery. Remote Sens. Environ. 2005, 98, 96-109. [CrossRef]

193. Mahapatra, P.; van der Marel, H.; van Leijen, F.; Samiei-Esfahany, S.; Klees, R.; Hanssen, R. InSAR datum connection using GNSS-augmented radar transponders. J. Geod. 2018, 92, 21-32. [CrossRef]

194. Ferretti, A.; Prati, C.; Rocca, F. Permanent scatterers in SAR interferometry. IEEE Trans. Geosci. Remote Sens. 2001, 39, 8-20. [CrossRef]

195. Arnaud, A.; Adam, N.; Hanssen, R.; Inglada, J.; Duro, J.; Closa, J.; Eineder, M. ASAR ERS interferometric phase continuity. In Proceedings of the IGARSS 2003. 2003 IEEE International Geoscience and Remote Sensing Symposium. Proceedings (IEEE Cat. No. 03CH37477), Toulouse, France, 21-25 July 2003; pp. 1133-1135.

196. Ferretti, A.; Fumagalli, A.; Novali, F.; Prati, C.; Rocca, F.; Rucci, A. A new algorithm for processing interferometric data-stacks: SqueeSAR. IEEE Trans. Geosci. Remote Sens. 2011, 49, 3460-3470. [CrossRef]

197. Berardino, P.; Fornaro, G.; Lanari, R.; Sansosti, E. A new algorithm for surface deformation monitoring based on small baseline differential SAR interferograms. Geosci. Remote Sens. IEEE Trans. 2002, 40, 2375-2383. [CrossRef]

198. Sowter, A.; Bateson, L.; Strange, P.; Ambrose, K.; Syafiudin, M.F. DInSAR estimation of land motion using intermittent coherence with application to the South Derbyshire and Leicestershire coalfields. Remote Sens. Lett. 2013, 4, 979-987. [CrossRef]

199. Costantini, M.; Falco, S.; Malvarosa, F.; Minati, F. A new method for identification and analysis of persistent scatterers in series of SAR images. In Proceedings of the Geoscience and Remote Sensing Symposium, 2008, IGARSS 2008, IEEE International, Boston, MA, USA, 7-11 July 2008; pp. II-449-II-452.

200. Blanco-Sanchez, P.; Mallorquí, J.J.; Duque, S.; Monells, D. The coherent pixels technique (CPT): An advanced DInSAR technique for nonlinear deformation monitoring. Pure Appl. Geophys. 2008, 165, 1167-1193. [CrossRef]

201. Bovenga, F.; Nutricato, R.; Guerriero, A.R.L.; Chiaradia, M. SPINUA: A flexible processing chain for ERS/ENVISAT long term interferometry. In Proceedings of the Envisat \& ERS Symposium, Salzburg, Austria, 6-10 September 2004 . ESA SP-572.

202. Catani, F.; Casagli, N.; Ermini, L.; Righini, G.; Menduni, G. Landslide hazard and risk mapping at catchment scale in the Arno River basin. Landslides 2005, 2, 329-342. [CrossRef]

203. Vilardo, G.; Isaia, R.; Ventura, G.; De Martino, P.; Terranova, C. InSAR Permanent Scatterer analysis reveals fault re-activation during inflation and deflation episodes at Campi Flegrei caldera. Remote Sens. Environ. 2010, 114, 2373-2383. [CrossRef]

204. Vilardo, G.; Ventura, G.; Terranova, C.; Matano, F.; Nardò, S. Ground deformation due to tectonic, hydrothermal, gravity, hydrogeological, and anthropic processes in the Campania Region (Southern Italy) from Permanent Scatterers Synthetic Aperture Radar Interferometry. Remote Sens. Environ. 2009, 113, 197-212. [CrossRef]

205. Solari, L.; Del Soldato, M.; Bianchini, S.; Ciampalini, A.; Ezquerro, P.; Montalti, R.; Raspini, F.; Moretti, S. From ERS 1/2 to Sentinel-1: Subsidence monitoring in Italy in the last two decades. Front. Earth Sci. 2018, 6, 149. [CrossRef]

206. Solari, L.; Del Soldato, M.; Raspini, F.; Barra, A.; Bianchini, S.; Confuorto, P.; Casagli, N.; Crosetto, M. Review of satellite interferometry for landslide detection in Italy. Remote Sens. 2020, 12, 1351. [CrossRef]

207. Herrera, G.; Mateos, R.M.; García-Davalillo, J.C.; Grandjean, G.; Poyiadji, E.; Maftei, R.; Filipciuc, T.-C.; Auflič, M.J.; Jež, J.; Podolszki, L. Landslide databases in the Geological Surveys of Europe. Landslides 2018, 15, 359-379. [CrossRef] 
208. Zijerveld, L.; Stephenson, R.; Cloetingh, S.; Duin, E.; Van den Berg, M. Subsidence analysis and modelling of the Roer Valley Graben (SE Netherlands). Tectonophysics 1992, 208, 159-171. [CrossRef]

209. Costa, A.L.; Kok, S.; Korff, M. Systematic assessment of damage to buildings due to groundwater lowering-induced subsidence: Methodology for large scale application in the Netherlands. Proc. IAHS 2020, 382, 577-582. [CrossRef]

210. Daalen, T.M.v.; Fokker, P.A.; Bogaard, P.J.; Meulen, M. Why we urgently need a public subsidence information service in the Netherlands. Proc. IAHS 2020, 382, 821-823. [CrossRef]

211. L'Heureux. A study of the retrogressive behaviour and mobility of Norwegian quick clay landslides. The Landslides Engineered Slopes: Protecting Society through Improved Understanding. In Proceedings of the 11th International \& 2nd North American Symposium on Landslides, Banff, AB, Canada, 2-8 June 2012; Taylor, Francis Group: London, UK, 2012; pp. $981-988$.

212. Subcommittee, P. Glossary of Permafrost and Related Ground-Ice Terms; Associate Committee on Geotechnical Research, National Research Council of Canada: Ottawa, ON, Canada, 1988; p. 156.

213. Sollid, J.; Sørbel, L. Palsa bogs at Haugtjørnin, Dovrefjell, South Norway. Norsk Geografisk Tidsskrift Nor. J. Geogr. 1974, 28 , 53-60. [CrossRef]

214. Lilleøren, K.S.; Etzelmüller, B. A regional inventory of rock glaciers and ice-cored moraines in Norway. Geogr. Ann. Ser. A Phys. Geogr. 2011, 93, 175-191. [CrossRef]

215. Shakesby, R.A.; Dawson, A.G.; Matthews, J.A. Rock glaciers, protalus ramparts and related phenomena, Rondane, Norway: A continuum of large-scale talus-derived landforms. Boreas 1987, 16, 305-317. [CrossRef]

216. Østrem, G. Ice-cored moraines in Scandinavia. Geogr. Ann. Ser. A Phys. Geogr. 1964, 46, 282-337.

217. Svensson, H. Ice-wedge casts and relict polygonal patterns in Scandinavia. J. Quat. Sci. 1988, 3, 57-67. [CrossRef]

218. Costantini, M.; Ferretti, A.; Minati, F.; Falco, S.; Trillo, F.; Colombo, D.; Novali, F.; Malvarosa, F.; Mammone, C.; Vecchioli, F. Analysis of surface deformations over the whole Italian territory by interferometric processing of ERS, Envisat and COSMOSkyMed radar data. Remote Sens. Environ. 2017, 202, 250-275. [CrossRef]

219. Di Martire, D.; Paci, M.; Confuorto, P.; Costabile, S.; Guastaferro, F.; Verta, A.; Calcaterra, D. A nation-wide system for landslide mapping and risk management in Italy: The second Not-ordinary Plan of Environmental Remote Sensing. Int. J. Appl. Earth Obs. Geoinf. 2017, 63, 143-157. [CrossRef]

220. Dehls, J.F.; Larsen, Y.; Marinkovic, P.; Lauknes, T.R.; Stødle, D.; Moldestad, D.A. INSAR. No: A National Insar Deformation Mapping/Monitoring Service In Norway-From Concept To Operations. In Proceedings of the IGARSS 2019-2019 IEEE International Geoscience and Remote Sensing Symposium, Yokohama, Japan, 28 July-2 August 2019; pp. 5461-5464.

221. Goel, K.; Adam, N.; Shau, R.; Rodriguez-Gonzalez, F. Improving the reference network in wide-area Persistent Scatterer Interferometry for non-urban areas. In Proceedings of the 2016 IEEE International Geoscience and Remote Sensing Symposium (IGARSS), Beijing, China, 10-15 July 2016; pp. 1448-1451.

222. Raspini, F.; Bianchini, S.; Ciampalini, A.; Del Soldato, M.; Solari, L.; Novali, F.; Del Conte, S.; Rucci, A.; Ferretti, A.; Casagli, N. Continuous, semi-automatic monitoring of ground deformation using Sentinel-1 satellites. Sci. Rep. 2018, 8, 1-11. [CrossRef]

223. Del Soldato, M.; Solari, L.; Raspini, F.; Bianchini, S.; Ciampalini, A.; Montalti, R.; Ferretti, A.; Pellegrineschi, V.; Casagli, N. Monitoring ground instabilities using SAR satellite data: A practical approach. ISPRS Int. J. Geo-Inf. 2019, 8, 307. [CrossRef]

224. Montalti, R.; Solari, L.; Bianchini, S.; Del Soldato, M.; Raspini, F.; Casagli, N. A Sentinel-1-based clustering analysis for geo-hazards mitigation at regional scale: A case study in Central Italy. Geomat. Nat. Hazards Risk 2019, 10, 2257-2275. [CrossRef]

225. Solari, L.; Del Soldato, M.; Montalti, R.; Bianchini, S.; Raspini, F.; Thuegaz, P.; Bertolo, D.; Tofani, V.; Casagli, N. A Sentinel-1 based hot-spot analysis: Landslide mapping in north-western Italy. Int. J. Remote Sens. 2019, 40, 7898-7921. [CrossRef]

226. Crosetto, M.; Solari, L.; Mróz, M.; Balasis-Levinsen, J.; Casagli, N.; Frei, M.; Oyen, A.; Moldestad, D.A.; Bateson, L.; Guerrieri, L. The evolution of wide-area dinsar: From regional and national services to the European ground motion service. Remote Sens. 2020, 12, 2043. [CrossRef]

227. Bruyninx, C.; Habrich, H.; Söhne, W.; Kenyeres, A.; Stangl, G.; Völksen, C. Enhancement of the EUREF permanent network services and products. In Geodesy for Planet Earth; Springer: Berlin/Heidelberg, Germany, 2012; pp. 27-34.

228. Intrieri, E.; Raspini, F.; Fumagalli, A.; Lu, P.; Del Conte, S.; Farina, P.; Allievi, J.; Ferretti, A.; Casagli, N. The Maoxian landslide as seen from space: Detecting precursors of failure with Sentinel-1 data. Landslides 2018, 15, 123-133. [CrossRef]

229. Rosi, A.; Tofani, V.; Agostini, A.; Tanteri, L.; Stefanelli, C.T.; Catani, F.; Casagli, N. Subsidence mapping at regional scale using persistent scatters interferometry (PSI): The case of Tuscany region (Italy). Int. J. Appl. Earth Obs. Geoinf. 2016, 52, 328-337. [CrossRef]

230. Raspini, F.; Bianchini, S.; Ciampalini, A.; Del Soldato, M.; Montalti, R.; Solari, L.; Tofani, V.; Casagli, N. Persistent Scatterers continuous streaming for landslide monitoring and mapping: The case of the Tuscany region (Italy). Landslides 2019, 16, $2033-2044$. [CrossRef] 